\title{
Heterocyclic Aromatic Amines in Meat: Formation, Isolation, Risk Assessment, and Inhibitory Effect of Plant Extracts
}

\author{
Hafiz Rehan Nadeem ${ }^{1}$, Saeed Akhtar ${ }^{1, *}$, Tariq Ismail ${ }^{1} \mathbb{D}$, Piero Sestili ${ }^{2} \mathbb{D}$, Jose Manuel Lorenzo ${ }^{3,4, * \mathbb{D}}$, \\ Muhammad Modassar Ali Nawaz Ranjha ${ }^{5, * \mathbb{D}}$, Leonie Jooste ${ }^{6}$, Christophe Hano ${ }^{7}$ (D) \\ and Rana Muhammad Aadil ${ }^{8, *(D)}$
}

\section{check for} updates

Citation: Nadeem, H.R.; Akhtar, S.; Ismail, T.; Sestili, P.; Lorenzo, J.M.; Ranjha, M.M.A.N.; Jooste, L.; Hano, C.; Aadil, R.M. Heterocyclic Aromatic Amines in Meat: Formation, Isolation, Risk Assessment, and Inhibitory Effect of Plant Extracts. Foods 2021, 10, 1466. https://doi.org/ $10.3390 /$ foods 10071466

Academic Editors: Luís Patarata and Maria João dos Ramos Fraqueza

Received: 1 June 2021

Accepted: 21 June 2021

Published: 24 June 2021

Publisher's Note: MDPI stays neutral with regard to jurisdictional claims in published maps and institutional affiliations.

Copyright: (C) 2021 by the authors. Licensee MDPI, Basel, Switzerland. This article is an open access article distributed under the terms and conditions of the Creative Commons Attribution (CC BY) license (https:// creativecommons.org/licenses/by/ $4.0 /)$
1 Institute of Food Science and Nutrition, Bahauddin Zakariya University, Multan 60800, Pakistan; hrnfoodscientist@gmail.com (H.R.N.); ammarbintariq@yahoo.com (T.I.)

2 Department of Biomolecular Sciences, University of Urbino Carlo Bo, 61029 Urbino, PU, Italy; piero.sestili@uniurb.it

3 Centro Tecnológico de la Carne de Galicia, Rúa Galicia N 4, Parque Tecnológico de Galicia, San Cibrao das Viñas, 32900 Ourense, Spain

4 Área de Tecnología de los Alimentos, Facultad de Ciencias de Ourense, Universidad de Vigo, 32004 Ourense, Spain

5 Institute of Food Science and Nutrition, University of Sargodha, Sargodha 40100, Pakistan

6 Environmental Health Sciences, Faculty of Communication, Arts and Sciences, Canadian University Dubai, Dubai 117781, United Arab Emirates; leonie.jooste@cud.ac.ae

7 Laboratoire de Biologie des Ligneux et des Grandes Cultures (LBLGC), INRA USC1328 Université d' Orléans, CEDEX 2, 45067 Orléans, France; hano@univ-orleans.fr

8 National Institute of Food Science and Technology, University of Agriculture, Faisalabad 38000, Pakistan

* Correspondence: saeedakhtar@bzu.edu.pk (S.A.); jmlorenzo@ceteca.net (J.M.L.); ModassarRanjha@gmail.com (M.M.A.N.R.); dilrana89@gmail.com (R.M.A.)

Abstract: Heterocyclic aromatic amines (HAAs) are potent carcinogenic compounds induced by the Maillard reaction in well-done cooked meats. Free amino acids, protein, creatinine, reducing sugars and nucleosides are major precursors involved in the production of polar and non-polar HAAs. The variety and yield of HAAs are linked with various factors such as meat type, heating time and temperature, cooking method and equipment, fresh meat storage time, raw material and additives, precursor's presence, water activity, and $\mathrm{pH}$ level. For the isolation and identification of HAAs, advanced chromatography and spectroscopy techniques have been employed. These potent mutagens are the etiology of several types of human cancers at the ng/g level and are 100- to 2000-fold stronger than that of aflatoxins and benzopyrene, respectively. This review summarizes previous studies on the formation and types of potent mutagenic and/or carcinogenic HAAs in cooked meats. Furthermore, occurrence, risk assessment, and factors affecting HAA formation are discussed in detail. Additionally, sample extraction procedure and quantification techniques to determine these compounds are analyzed and described. Finally, an overview is presented on the promising strategy to mitigate the risk of HAAs by natural compounds and the effect of plant extracts containing antioxidants to reduce or inhibit the formation of these carcinogenic substances in cooked meats.

Keywords: heterocyclic aromatic amines; carcinogens; cooked meat; inhibition; natural antioxidants

\section{Introduction}

Our diet contains meat as a significant food that contributes valuable constituents and nutrients such as all essential amino acids, high-quality proteins, vitamin B6, niacin, iron, vitamin B12, phosphorus, zinc, and selenium, as well as other biologically active materials, including carnosine, taurine, carnitine, glutathione, creatine, and ubiquinone, that are considered beneficial for human health [1-4]. Meat is usually cooked to enhance its palatability and safety [5]. Nevertheless, the temperature required for heat processing 
enables reactions between the components characterized in fish and meat, producing genotoxic compounds [6]. Numerous epidemiological analyses have revealed that a high consumption of meat with different practices of cooking is related to an augmented menace of various cancers in humans, including breast, colon, pancreatic, and prostate cancers [7,8]. Numerous studies have discovered that different procedures of cooking are employed, with elevated temperatures above $150{ }^{\circ} \mathrm{C}$, to cook meat-based products [9], including grilling [10], smoking [11], roasting [12], frying, and barbecuing [13]. As a result of cooking at high temperatures, heterocyclic amines of aromatic compounds are formed.

Heterocyclic aromatic amines (HAAs) can be defined as a main class of compounds that are potentially carcinogenic and extracted from proteinaceous foods during flavor forming and processing using heat [14]. Professor Sugimura was the first person who discovered HAAs, and, at present, 30 different mutagenic HAAs have been identified in protein-rich cooked foods [15]. When specific foods rich in protein, such as pork, chicken, fish, and beef, are cooked for a longer time, a kind of heterocyclic amine of aromatic components is neo-formed [16]. Polycyclic aromatic hydrocarbons (PHAs) and heterocyclic amines (HAAs) are recognized by means of being carcinogenic and/or mutagenic compounds that are available in parts per billion levels of broiled meat $[9,17]$.

Nevertheless, numerous epidemiological studies have demonstrated the relationship between the consumption of meat and an elevated risk of occurrence of different types of cancers [18] due to the formation of HAAs, hypothesized to be a cancer menace biomarker [19]. Subsequently, a higher intake of processed and red meat predominantly transports the menace of colorectal tumors [20]. Various analyses have uncovered that meat consumption elevates the risk of numerous kinds of cancer by up to 50\% [21]. The International Agency for Research on Cancer (IARC) has reported the classification of processed and red meat and its consumption as a predominant cancer-causing factor in humans. Groups $2 \mathrm{~A}$ and $1 \mathrm{~B}$ are two major groups formed with the recommendation of HAA exposure [22].

Studies have demonstrated that regular intake of grilled meat with HAAs may enhance the risk of cancer in different organs of humans [21]. It has been recommended that the exposure of these components to humans should be lessened [23]. Effective HAA inhibitors have been identified, which are needed significantly. Moreover, antioxidants that are added to meat before cooking are considered the most effective and promising HAA inhibitors at different levels [24]. It is suggested that the Maillard and free radical reactions have a combined effect on the production of HAAs, establishing pathways. In the initial levels of the Maillard reaction, antioxidants may responsibly act as scavengers of free radicals, which decreases the formation of HAAs [25].

Products from natural sources have been used for centuries [26,27]. Plants, because of their phytochemical profile, have emerged as the best resource to fight against different disorders and diseases [28,29]. Numerous systems of food have been studied with the aim of reducing or inhibiting HAA formation, with the commitment to decrease the developing risk of chronic diseases. Different methods of cooking, utilizing food additives with the presence of natural antioxidative compounds such as phenolics [30], can cause a reduction in HAA formation in cooked meats. The presence of natural antioxidants in herbs and spices has received considerable attention for use as proficient inhibitors, also working against the mutagenic formation of HAAs in processed meat [31-33]. Pomegranate seed extracts [34,35], grape seed extracts [36] olive and apple extracts [28,37], spices such as lemongrass, turmeric, and torch ginger [32,38], herbs such as savory, thyme, and oregano [39], galangal and fingerroot [15], vitamin E that is lipid-soluble [40], and vitamins that are water-soluble [41] have been reported to inhibit HAA formation in the food systems.

The existence of HAAs in sufficiently heated food matrices and the monitoring of the negative effects of these toxic compounds on human health and the inhibition of their existence in cooked food is an obligatory requirement. This review demonstrates the delivery of detailed information about HAAs that is based on the knowledge from proceedings to advanced studies. Numerous pretreatments and methods are applied in 
different samples of food and clarify the different techniques for the analysis, determination, and isolation of HAAs. Finally, an overview is presented on a promising strategy to mitigate the risk of HAAs by natural compounds and the effect of plant extracts containing antioxidants to reduce or inhibit the formation of these carcinogenic substances in cooked meats.

\section{Occurrence of HAAs}

The identification of HAAs in various foods, such as cooked fish and meats, products of meat, extracts of meat [42], coffee [43], extracts of meat oils [44], food flavors, and alcoholic drinks, and in environmental sources (surface and air-water) and biological and industrial fluids as well as cigarette smoke and kitchen fumes have been determined [45].

Quantities of HAAs vary in the case of meat from different animal species, for example, fish, poultry, pork, and beef. For example, a great occurrence of PhIP (2amino-1-methyl-6-phenylimidazo[4,5-b]pyridine) and IFP (2-amino-1,6-dimethyl-furo[3,2e]imidazo[4,5-b]pyridine) in poultry has been observed while more MeIQx (2-amino-3,8dimethylimidazo[4,5-f]quinoxaline) is observed in pork, fish, and beef [46]. It is well observed that MeIQx, after PhIP, is regarded as the second most abundant HAA [8]. The household methods of cooking mostly cause the formation of HAA levels in meat in small ranges $(0.1-50 \mathrm{ng} / \mathrm{g})$ [47].

Gibis and Weiss [48] conducted a study to assess the impact of precursors creatine, creatinine, and glucose on the formation of heterocyclic aromatic amines in grilled patties of various animal species. In their study, the meats of veal, beef, pork, lamb, horse, venison, turkey, chicken, and ostrich were investigated. They found that the MeIQx content in grilled patties of various animal species ranged from 0.49 to $1.35 \mathrm{ng} / \mathrm{g}, 4,8$-DiMeIQx ranged from 0.05 to $1.27 \mathrm{ng} / \mathrm{g}$, PhIP ranged from 0.17 to $10.47 \mathrm{ng} / \mathrm{g}$, Norharman ranged from 0.55 to $1.88 \mathrm{ng} / \mathrm{g}$, and Harman ranged from 0.07 to $3.18 \mathrm{ng} / \mathrm{g}$ [48]. Similarly, Gibis and Loeffler [49] conducted a study of creatine and glucose on the formation of heterocyclic amines in grilled chicken breasts. They found different HAA ranges, namely, 0.55-2.16 (Harman), 0.74-2.29 (Norharman), 1.49-9.05 (PhIP), and 0-1.12 (MeIQx) ng/g [49]. The significant occurrence of PhIP and IFP in poultry was observed, while more MeIQx was observed in pork, fish, and beef [46].

\section{HAA Formation}

The amines of heterocyclic compounds are divided into groups of carcinogenic and mutagenic compounds that are produced on the surface of foods rich in protein, such as fish and animal meats [38], and result in the development of the Maillard complex reaction during roasting and frying [50]. Both polar and non-polar HAAs (Harman and Norharman) are produced at lesser temperatures [18]. It is suggested that free radical compounds play a significant role in the IQx- (2-amino-3-methyl-3 H-imidazo [4,5-f]quinoxaline) and IQ- (2-amino-3-methyl-3 H-imidazo[4,5-f)quinolone) type HAA formation that is mostly developed through Strecker degradation radicals and creatinine condensation (pyrazines and pyridines) reactions. The Maillard reaction is mostly applicable during amino acid reactions and glucose generation [51].

Reducing sugars, creatinine, and phenylalanine can be distinguished in the formation of PhIP. In these studies, scientists have identified the reaction, which leads to the formation of PhIP, by following steps through a model experiment. Firstly, the formation of phenylacetaldehyde occurs from phenylalanine through the degradation of the Strecker reaction. Then, the formation of phenylacetaldehyde is complete during a reaction with aldol and creatinine to develop an additional aldol product. PhIP is formed from the condensation of aldol by a subsequent condensation reaction [52]. Figure 1 shows the reaction mechanism of compound formation. 


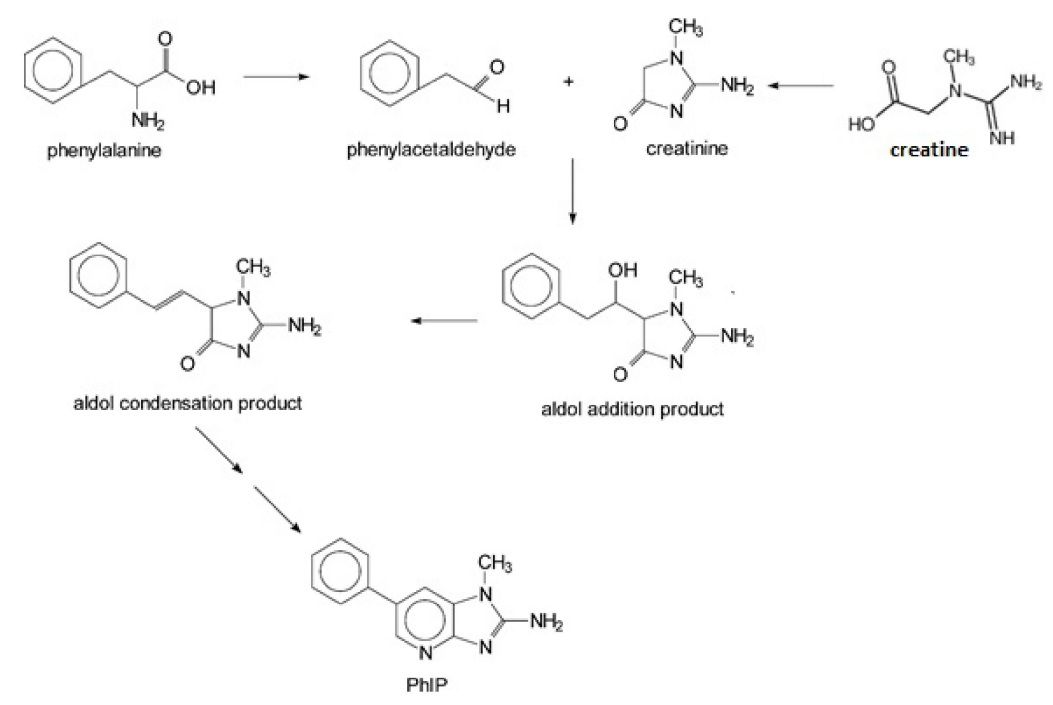

Figure 1. PhIP chemical formation reaction.

Precursors and Factors Affecting HAA Formation

Reducing sugars, such as fructose and glucose, are produced directly by sucrose hydrolysis of free amino acids and creatinine, available naturally in muscular mammalian tissue and referred to as the potential precursors, accountable for HAA formation. Moreover, various precursors such as creatinine, free amino acids, nitrogenous bases, sugars, protein, and nucleosides are produced at different levels of raw material processing [53]. The variety and content of HAAs in cooked foods are determined by various factors such as the quantity of meat, fresh meat storage time, the kind of raw material, physical aspects of the heat conduction such as duration of heating and temperature, equipment for cooking, the method of processing, the presence of inhibitors or enhancers, the level of doneness, the activity of water, and, particularly, $\mathrm{pH}$. All the abovementioned factors speed up the production of HAAs and have a greater effect on the reaction of HAA formation [18,54].

HAAs are not affected by the variations in $\mathrm{pH}$ in the actual sense. HAA precursors are sensitive to $\mathrm{pH}$ changes by which the formation of HAAs can ultimately be affected. Enhanced $\mathrm{pH}$ levels can modify the formation pathways of HAA precursors and lead to minimum HAA production. HAAs are sensitive to the contents and oxidation of lipids, and their formation is also affected by the availability of antioxidants [55].

Polak et al. [56] conducted research on the influence of temperature on the formation of heterocyclic aromatic amines in pork steaks. They found that HAA levels increased with increasing grilling temperature. A very similar study was conducted by Knize et al. [57] to assess the effect of cooking time and temperature on the heterocyclic amine content of fried beef patties. They also reported the elevation of HAA levels with increased temperature and time.

In addition, the quantity of meat fat has a noticeable impact on the formation of HAAs, and it is believed that HAA concentration is lower in fat-rich meat than other kinds of meat. The transportation of high heat is required in fat-rich meat to enhance the time of cooking compared to lean meat [58]. The influence of animal species on the formation of HAAs in marinated meat has been described [16].

It is hypothesized that the higher concentrations of free amino acids and total creatine are linked to the development of HAAs in more quantity during the treatment of thermal heat; a correlation that was quite strong was noted between these features. Despite the detailed fact that the concentration of HAAs somehow originates from reducing sugars, only frail interdependence was attained from these parameters [59]. It was revealed that numerous HAAs could be obtained by amino acids heated with creatine with no addition of sugar to the system of the model. Amino acids play a more substantial role in HAA formation than sugar. Creatine is considered as a major precursor in the formation of polar 
HAAs, which carry a dominant reaction with products obtained by Maillard reaction to form more polar HAAs [60]. Bordas et al. [61] revealed that the quantities of Harman, Norharman, and MeIQx were enhanced in a meat-flavored model system with a 50-fold increase in glucose. Tai et al. [62] observed that the quantities of HAAs were enhanced in fried fish, especially when frying by adding $9 \%$ sugar, although reduced when $19 \%$ sugar was used when frying. The results predict that the addition of more sugar during frying attributes to the production of Maillard products with less HAAs. The creatinine that reacts with Maillard products also acts as a precursor for HAA formation [18]. Wu et al. [63] described the process of cooking in ethanol and demonstrated that ethanol enhanced IQ and IQx formation, depending on the dose concentration. Increased concentrations of ethanol also increased the rate of browning in the solution [63]. The contents of Norharman and Harman were increased and significantly affected by the presence of fructooligosaccharides, which was observed predominately in the previous study [64]. Liao et al. [65] observed the reactions of Ile, Glu, Phe, Tyr, Ser, and Thr with glucose, which developed HAAs in pork floss.

Skog [66] observed that Tyr boosted the production of IQx compounds, and high quantities of Ala, Phe, and Gly favored PhIP and MeIQx formation in moist states. It has also been reported that soy albumin proteins, globulin proteins, gluten, and casein are formed with HAAs at temperatures above $250^{\circ} \mathrm{C}$; nevertheless, the process has not been completely clarified [67].

\section{Types of HAAs}

HAAs are considered analytes that are hazardous, and, therefore, they are categorized into two major groups according to their reactions of formation. They can be grouped into pyrolytic and thermic HAAs. Thermic HAAs can be produced by free amino acid reactions containing hexoses and creatinine at temperature ranges between $100-300{ }^{\circ} \mathrm{C}$. They are also recognized as aminoimidazoazarenes and the IQ type. Pyrolytic HAAs are produced at temperatures above $300^{\circ} \mathrm{C}$, and pyrolytic reactions are applied between proteins and amino acids for the formation of hazardous compounds $[18,68]$.

In another survey, HAA formation was detected diversely. The study described that HAAs are divided into two major groups known as polar HAAs (IQ type) and nonpolar HAAs (non-IQ type), depending on their structure, temperature, and formation pathways [69]. The group of polar compounds is formed from amino acids, creatinine, and carbohydrates at a temperature range between $150-250{ }^{\circ} \mathrm{C}$. It is observed that polar HAA compounds initiate their formation with the Millard reaction, especially various free amino acids and glucose between reducing sugars $[47,70]$. The creatinine condensation terminates HAA formation with pyrazine and pyridine and with the intermediate free radical of the Maillard reaction. The non-polar HAA group is formed from the pyridoindole or dipyridoimidazole moiety from amino acid pyrolysis, such as glutamic acid, lysine, phenylalanine, tryptophan, and ornithine, except for creatinine, at temperatures more than $250^{\circ} \mathrm{C}[41,71]$.

In another study by Sahar et al. [72], HAAs are classified based on ring structure, as follows:

- Five-membered amines of a heterocyclic nature;

- Six-membered amines of a heterocyclic nature.

Five-membered amines of heterocyclic compounds include five ring atoms. The structure of these cyclic compounds is comprised of four carbon atoms and one nitrogen atom. The main examples of these compounds are pyrrole and nicotine. The six-membered structure of amines of heterocyclic compounds show more similarity towards benzene; the difference is where nitrogen substitutes the carbon atom in the structural ring [72].

Abbreviations, names of compounds, structure, molecular mass, chemical formulas, and the non-polar and polar presence of HAAs in different varieties of foods are mentioned in Table 1. 
Table 1. Structure, abbreviation, compound name, chemical formula, molecular mass, and presence of polar and non-polar HAAs in foods.

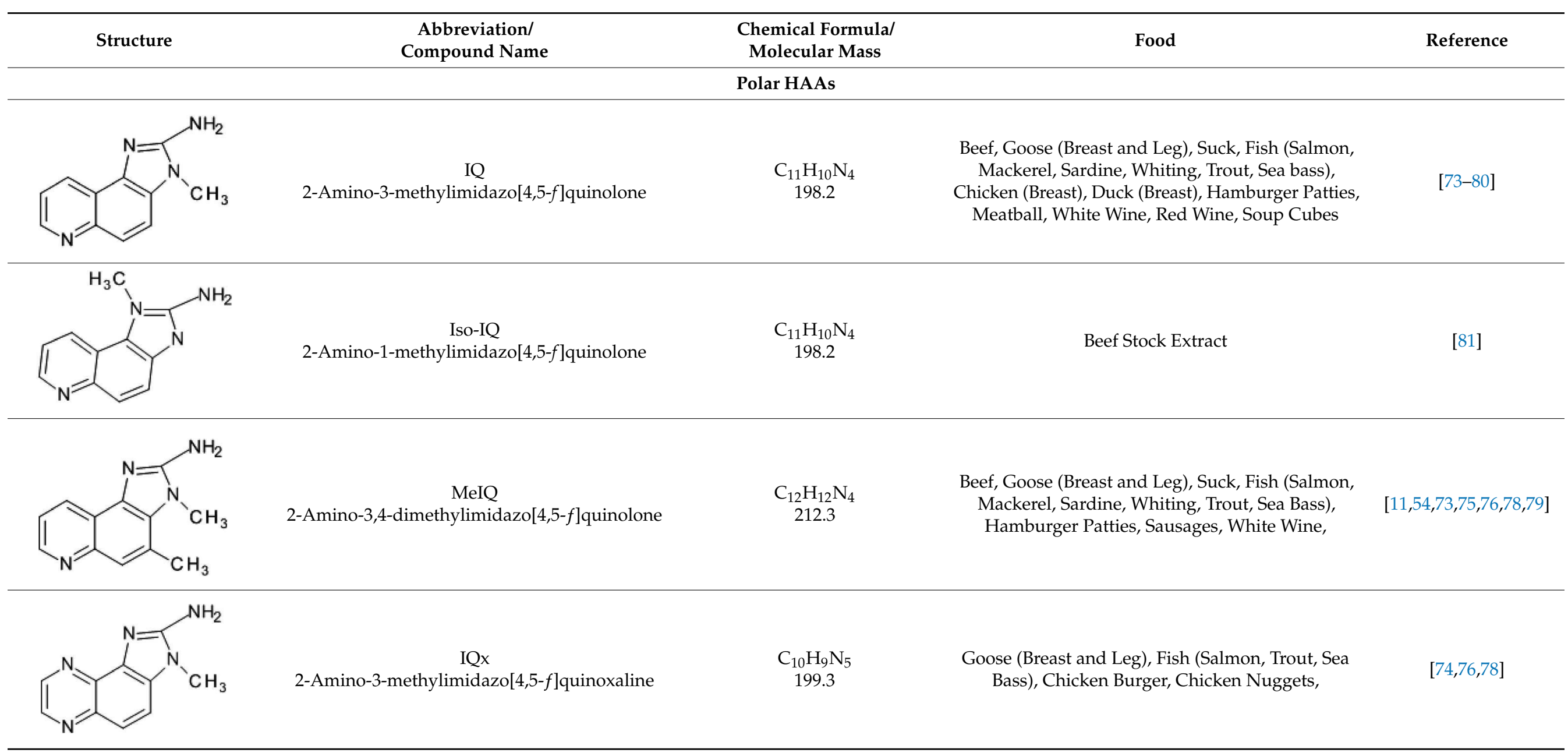


Table 1. Cont

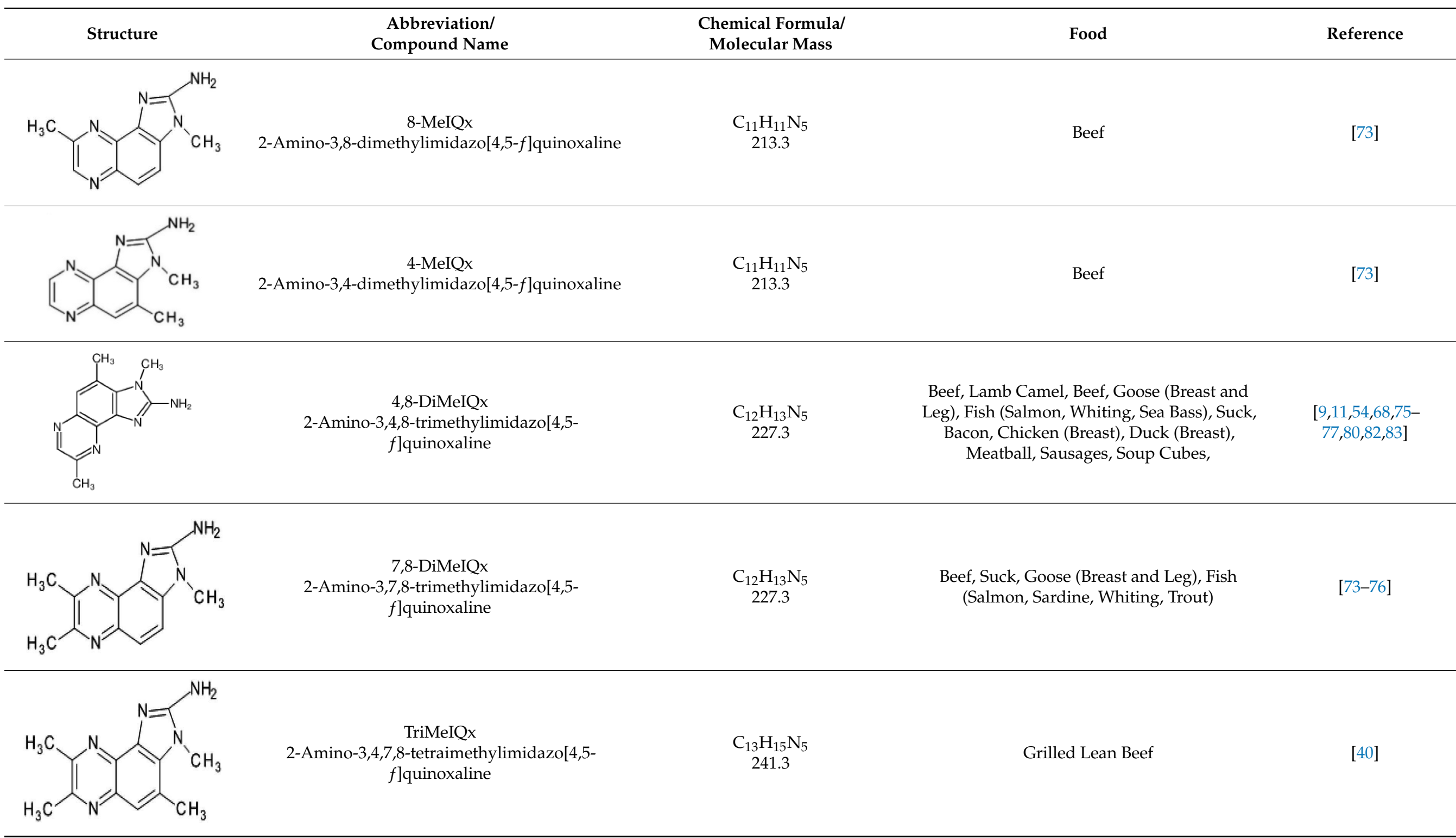


Table 1. Cont.

\begin{tabular}{|c|c|c|c|c|}
\hline Structure & $\begin{array}{l}\text { Abbreviation/ } \\
\text { Compound Name }\end{array}$ & $\begin{array}{l}\text { Chemical Formula/ } \\
\text { Molecular Mass }\end{array}$ & Food & Reference \\
\hline $\mathrm{H}_{3} \mathrm{C} \quad \mathrm{H}_{3}$ & $\begin{array}{l}\text { 7-MeIgQx } \\
\text { 2-Amino-1,7-dimethyl-1H-imidazo[4,5- } \\
\text { g]quinoxaline }\end{array}$ & $\begin{array}{l}\mathrm{C}_{11} \mathrm{H}_{11} \mathrm{~N}_{5} \\
213.2\end{array}$ & $\begin{array}{c}\text { Pork (Chops, Bacon, Sausage Patties), Chicken } \\
\text { (Breast, Boneless) }\end{array}$ & {$[11,84]$} \\
\hline & $\begin{array}{c}\text { 7,9-MeIgQx } \\
\text { 2-Amino1,7,9-tridimethyl-1H-imidazo[4,5- } \\
\text { g]quinoxaline }\end{array}$ & $\begin{array}{l}\mathrm{C}_{12} \mathrm{H}_{13} \mathrm{~N}_{5} \\
227.3\end{array}$ & Fried Beef, Barbecued Chicken & [85] \\
\hline & $\begin{array}{l}\text { PhIP } \\
\text { 2-Amino-1-methyl-6-phenyl-imidazo[4,5- } \\
\text { b]pyridine }\end{array}$ & $\begin{array}{c}\mathrm{C}_{13} \mathrm{H}_{12} \mathrm{~N}_{4} \\
224.3\end{array}$ & $\begin{array}{c}\text { Cheese, Beef, Lamb Camel, Suck, Bacon, Pork } \\
\text { Loin, Fish (Salmon, Mackerel, Sardine, Whiting, } \\
\text { Trout, Sea Bass), Chicken (Breast), Duck } \\
\text { (Breast), Chicken Burger, Meatball, Sausages, } \\
\text { Beer, White Wine, }\end{array}$ & $\begin{array}{c}{[11,68,73,75-} \\
77,79,82,86-88]\end{array}$ \\
\hline & $\begin{array}{c}4^{\prime} \mathrm{OH}-\mathrm{PhIP} \\
\text { 2-Amino-1-methyl-6-(4'hydroxyphenyl)- } \\
\text { imidazo[4,5-b]pyridine }\end{array}$ & $\begin{array}{c}\mathrm{C}_{13} \mathrm{H}_{12} \mathrm{~N}_{4} \mathrm{O} \\
240.6\end{array}$ & Fried and Grilled Chicken Breast & [89] \\
\hline & $\begin{array}{c}\text { DMIP } \\
\text { 2-Amino-1,6-dimethylimidazo[4,5-b]pyridine }\end{array}$ & $\begin{array}{c}\mathrm{C}_{8} \mathrm{H}_{10} \mathrm{~N}_{4} \\
162.2\end{array}$ & Pork Fried Meat Emulsion & {$[90]$} \\
\hline
\end{tabular}


Table 1. Cont.

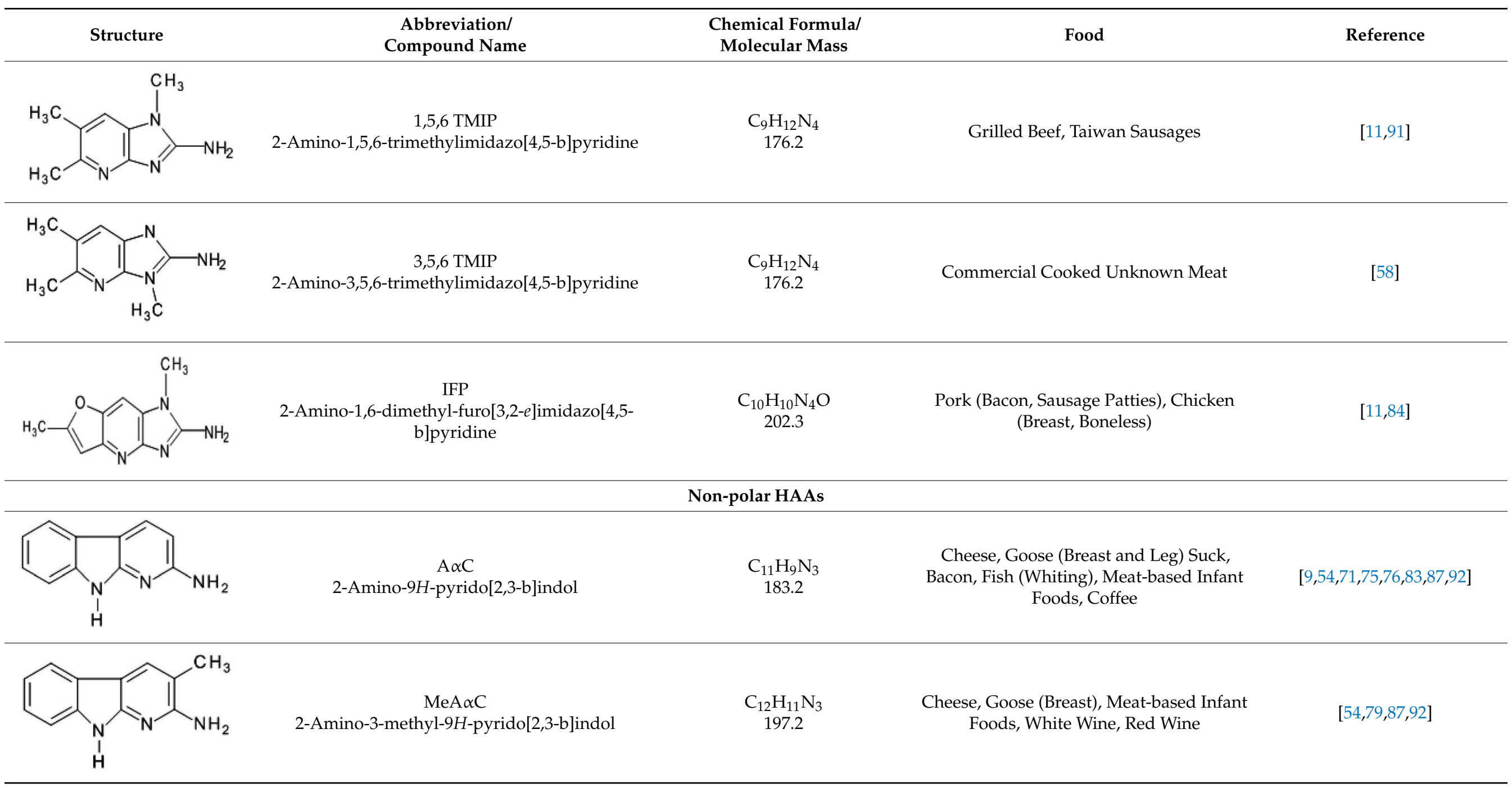


Table 1. Cont.

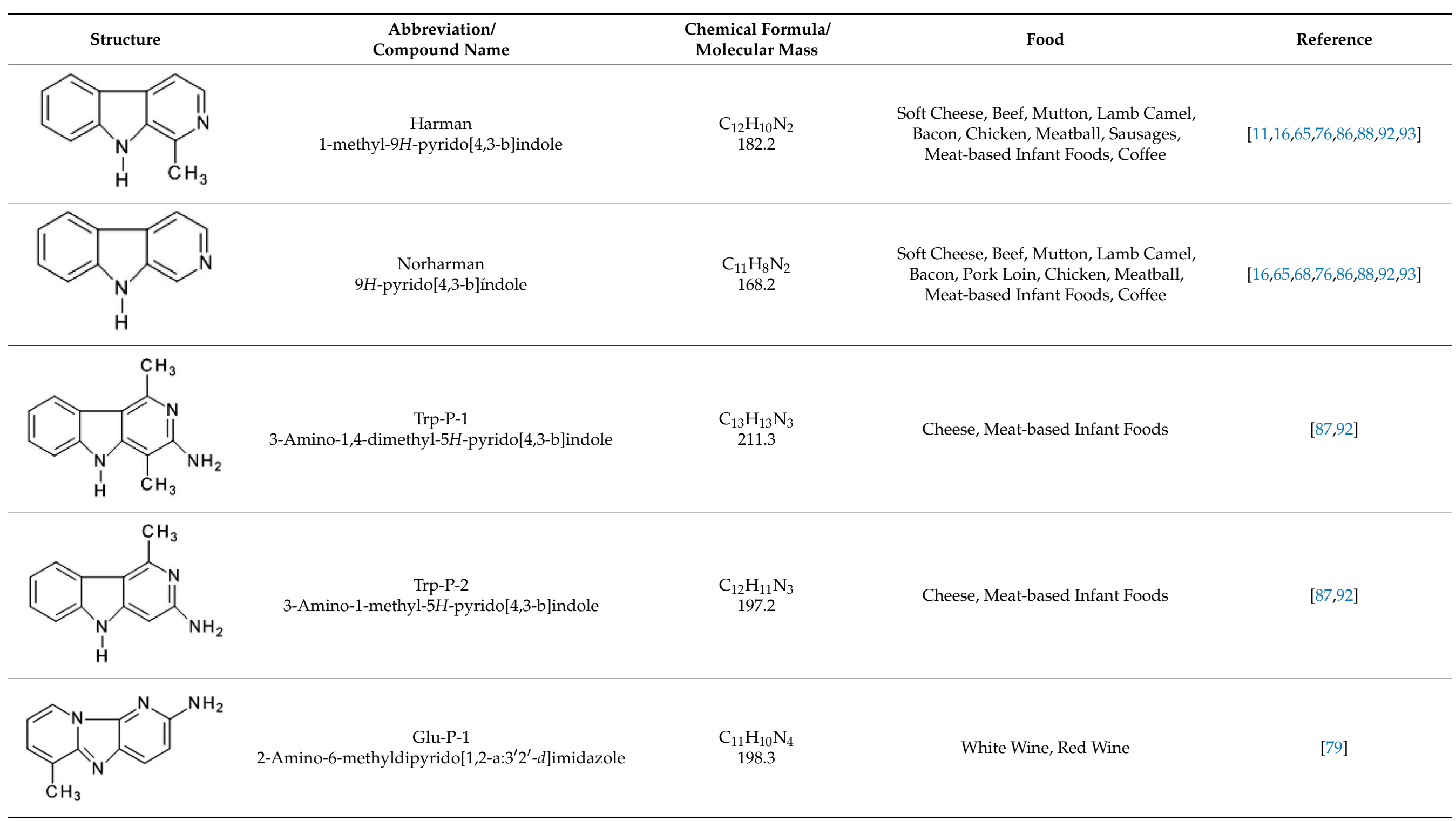


Table 1. Cont.

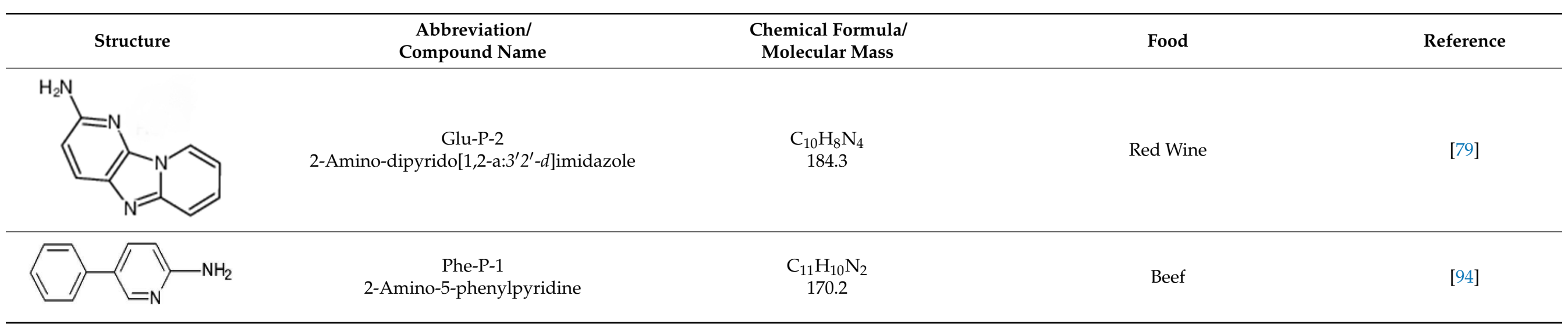




\section{Quantification and Identification}

Progressive extraction procedures and instrumental methods have been applied for the detection and separation of HAAs. According to the kind of preparation of the sample, the experiment's sensitivity, and the choice of systematic equipment, laboratory, and accessible facilities will be dissimilar [14].

Colorimetric procedures have been established for the measurement of amines, including biogenic compounds and copper ions. This experiment includes a detection limit of about $5 \mathrm{mg} / \mathrm{kg}$ and enumerates the amines of biogenic compounds by $496 \mathrm{~nm}$ value of absorbance with the assistance of a spectrophotometer. The procedure has the benefit of considering only $45 \mathrm{~min}$ of analysis. Furthermore, the method is also determined as a method of cost-effectiveness and does not need specialized laboratory equipment [95].

Fluorescence synchronous spectroscopy has been utilized to enumerate the quantity of numerous HAAs in meat samples that were heated by the measured condition [72]. The most frequently utilized procedure of sample treatment for the detection of HAAs is the adapted Grüter and Gross method, which depends on the SPE's three steps of purification and alkalization, for example, the columns coupled with diatomaceous earth, RP-phase 18, and sulfonic propyl acid [96]. Such a multistep procedure of pretreatment takes substantial time, with a large number of reagents and chemicals. Briefly, the recoveries attained from these frequently used approaches to pretreatment are unacceptable for all HAAs targeted. In the Grüter and Gross method, the efficiencies of extraction through all levels of purification procedures are better than 53\% $\alpha$-carboline amines and $41 \%$ PhIP. Similarly, utilizing various procedures, the authors of [97] showed an instantaneous investigation of 14 HAAs in barbecued samples of salmon and sardines. The establishment of electrophoresis of the capillary process and the procedure of in-line preconcentration for the determination of 16 HAAs simultaneously were examined [98].

Yan et al. [99] anticipated an accurate and simple acetonitrile extraction method of pretreatment, equipped with high ultra-performance liquid chromatography to mass tandem spectrometry for the instantaneous measurement of 17 HAAs in meat products. In addition, recent studies have measured instantaneous 15 HAAs in grilled fish utilizing high ultra-performance liquid chromatography; the solid extraction phase (SPE) with ionization electrospray mass tandem spectrometry (ES-UHPLC-MS) has been described by Feng et al. [100].

In recent studies, nine retrievals for HAAs were more than 50\% extra (51-68\%), although 1-mehyl-3-amino 5H-indole pyrido, 3-amino 1,4-5Hdimethyl- indole pyrido, $\mathrm{PhIP}$, 2-amino-9H-pyrido-indole, and $(\mathrm{MeA} \alpha \mathrm{C})$ 2-methyl-amino-3-9H-indole-pyrido had the range of $23 \%-32 \%$ (Costa et al., 2009). In additional recent studies, 15 targeted recoveries of HAAs were ranged between $35 \%-70 \%$, commonly consumed in pan-fried beefsteak. Among the 15 HAAs targeted, the rates of recovery for 4,8-trimethyl-2-amino-3 quinoxaline imidazo (4,8-DiMeIQx) and (Norharman) 9H-pyrido-indole reached $42.7 \%$ and $35.9 \%$ correspondingly [101]. Subsequently, the problems of analysis for a long time preparation had a recovery that was unsatisfactory during the process of pretreatment, which designates the requirement for an improved analysis procedure to enumerate various HAAs instantaneously. Currently, HPLC is only the technique that can moderately, accurately, and reliably quantify and detect HAAs in meat samples of cooking. Consequently, it is the utmost reliable technique for the analysis of food. Presently, the extraction of HAAs is determined by advanced methods such as the extraction phase of solids and the extraction of liquids and solids. Ultra-performance liquid chromatography (UPLC), gas chromatography (GC), and mass spectrometry (MS) specifically analyze the phases [102] Sahar et al. [72] utilized fluorescence synchronous spectroscopy (FSS) coupled with HAA quantification of chemometrics in samples of grilled meat. Jautz et al. [103] quantified HAAs in fried meat by HPTLC/UV-FLD and HPLC/UV-FLD. Sentellas et al. [98] determined HAAs by capillary electrophoresis coupled to mass spectrometry using in-line preconcentration. Vanderlaan et al. [104] used enzyme-linked immunosorbent assays for HAA determination. 


\section{HAA Risk Assessment}

The salmonella or Ames test demonstrates that maximum HAAs are extremely mutagenic [105], and HAAs are entirely recognized as carcinogenic compounds in toxicology studies [14]. Cancer development is mostly lead by HAAs, which cause the mutation of genes and abnormal patterns of growing cells [106]. Several research discoveries have established that HAAs can modify DNA, such as chain hydrogen bond breaking in DNA, mutations in site, and deletions and insertions in DNA [9]. These compounds show extreme mutagenesis; they have almost ten times the carcinogenicity of other poisonous compounds such as aflatoxins B1, nitrosamines, and pyrene benzo compounds [107]. The HAAs are more than 100-fold more mutagenic than aflatoxins B1 and 2000-fold more mutagenic than pyrene benzo compounds when compared to other mutagens in food [81]. The HAA compounds are engrossed in the small intestine of the body and, afterward, move to the liver and are triggered in this organ [108]. The activation of metabolic HAAs begins with $\mathrm{N}$-oxidation by enzymes of the cytochrome, and the reaction of acetylation is compulsory for this stage of activation [109]. The product of $\mathrm{N}$-acetoxyamine, which is mentioned above in the reaction, is a reactive molecule that can bring damage to DNA and cause mutations [110].

According to the inspection description of the National US Program of Toxicology, HAA uptake ranges above $17 \mathrm{ng} / \mathrm{kg}$ of body weight show a strong correlation with the intake of meat-based cooked products. The continuing survey also commented that individuals who consume products of meat are mostly accountable for HAA accumulation in the body [111]. The exposure of HAAs to the human body is also affected by the method of cooking as well as the kind of food. Many other factors, such as frequency of consumption and size of portion, are also involved [112]. The indication of daily estimated levels of HAA consumption ranges from $0-15 \mathrm{mg} /$ day according to the diet per person. In the current study, HAA consumption is less than $1 \mathrm{mg}$, most probably in the case of consumption of $100 \mathrm{~g}$ of medium chops in the control group, with the molecular weight of chitosan heated at $250{ }^{\circ} \mathrm{C}$, which acquired the highest quantity of HAAs (4.21 ng/g) [54].

The Europe Council advises that the quantity of HAA consumption must have a lower quantity than $1 \mu \mathrm{g}$ per day [113]. Although the quantity of daily consumption of HAAs is diverse in numerous epidemiological surveys, the studies have assessed that the calculated daily consumption of HAAs has a quantity of about $420 \mathrm{ng} / \mathrm{d}$ per person. Wolk [114] emphasized that $50 \mathrm{~g}$ per day consumption of meat increases the carcinogenic probability; the colonic cancer rate is estimated at $18 \%$, prostate about $4 \%$, breast $9 \%$, and pancreatic cancer at $19 \%$. The mutagenic compounds of HAAs noticed in commercial products of meat and heated meat is based on homemade standards; the level ranges from $1-100 \mathrm{ng} \mathrm{g}^{-1}$ [99].

Frequently, cases of colon cancer are reported to be about 7-9\% due to red meat consumption with HAAs [115]. Rohrmann et al. [116] investigated that HAA consumption can be above $41.4 \mathrm{ng} /$ day, which increases the colorectal tumor risk. Szterk [117] showed that digestion in the digestive tract of humans may involve HAAs that are unrestricted and demonstrate a significant carcinogenesis role. Consequently, the hazard and formation of HAAs in broiled foods have created public anxiety for the health of consumers. The surveys of epidemiological studies have established that the risk is enhanced in colon, breast, pancreatic, prostate, stomach, and other cancers, which are linked with well-cooked red meat intake, related closely to HAAs [118-122]. Cancer in the lung is mostly caused by HAAs that are responsible for cancer onset [123]. The HAAs' carcinogenicity has also been recognized in animal experiments. Recent studies have demonstrated the HAAs mutagenicity in bacteria [124], investigational animals, and the cells of mammals [125]. Four HAAs (MeIQ, IQ, PhIP, and MeIQx) are recorded in the 11th Carcinogens survey report by the Department of US Human and Health Services in 2005 as constituents that are reasonably expected to cause carcinogenesis in humans. 


\section{HAA Inhibition by Natural Extracts}

Various risks are linked with the intake of HAAs; decreasing the exposure of HAA development by diminishing proteinaceous foods, cooking with reduced cooking time and temperatures [55], and a reduction in meat storage are also recommended. Szterk and Jesionkowska [42] suggested the consumption of meat that has more fat rather than low-fat meat. Marinating meat with diverse spices and herbs $[39,126]$ and the pretreatment of meat [53] are the methods proposed to reduce the formation of HAAs in meat.

Numerous studies have exposed the effects of inhibition with synthetic antioxidants (butylated hydroxytoluene (BHT), butyl tertiary hydroquinone [69], butylated hydroxyanisole (BHA) [127]) or natural antioxidants such as polyphenols [128], white green and black flavonoids from tea [129,130], the chrysin flavonoid [85], flavonoids in citrus [131], ellagic acid [132], vitamin E and C [40], propyl gallate (PG), extracts of plant or fruit [126,133], beer [134], wine [135], and numerous spices [25] on the formation of HAAs in meat-based products. Polyphenols have been designated for the inhibition of HAA production via the free radicals formed from the Maillard reaction [136].

Pomegranate seed extracts [35], olives and apples [37], herbs such as savory, oregano and thyme [39], the seeds of grapes [36], spices such as torch ginger, lemongrass, and turmeric [38], soluble lipid vitamin E [40], vitamins soluble in water [41], and galangal and fingerroot [15] have been suggested to prevent HAA formation in systems of food. The accumulation of black pepper powder and turmeric [55], hibiscus [137], and extracts of marjoram, oregano, rosemary, coriander, and savory [39] are regarded as ingredients of marinades before cooking that decrease HAA content. The formation of HAAs was suppressed by the formation of free radicals scavenging in HAA formation pathways [122].

The reduction in the degree of HAAs seems to be based on the concentration and potency of the plant extracts as well as extractions of HAA concentration in the samples of meat. The results show that except for the determination of the property of antioxidants, which is an important feature in the reduction of HAA formation, other features in the ingredients of marinades have a major contribution to the extraction of precursors from the HAAs at different concentrations, including amino acids and glucose that also influence the reduction or formation of HAAs [33]. The inhibition of total formation of HAAs occurred at different percentages of $47 \%, 50 \%, 46 \%$, and $54 \%$ by galacto-oligosaccharide, isomalto-oligosaccharide, inulin, and fructo-oligosaccharide applications, respectively, at the dose of $1.5 \mathrm{~g} / 100 \mathrm{~g}$ in patties of ground beef [138]. Gibis et al. [139] reported that HAA formation could be inhibited with the addition of fibers of cellulose. In other research, Hasnol et al. (2014) described a reduction in PhIP, MeIQ, Norharman and MeIQx levels in grilled marinated chicken by using honey, table sugar, and brown sugar before cooking [7]. Balogh et al. [73] conducted a study in which they reported that (1-10\%) vitamin E addition before frying in the beef can meaningfully decrease the formation of HAAs at various levels. The inhibition of tocopherol is the reason behind the free radical's formation, which is essential as one of the HAAs' precursors [73].

Tengilimoglu-Metin et al. [140] described that the extract of hawthorn at $1 \%$ and $0.5 \%$ reserved the formation of Norharman and Harman correspondingly. It mostly happens due to the occurrence of phenolic complexes comprising proanthocyanins and flavonoids in the extracts of hawthorn [140]. Sabally et al. [115] observed that the extract of polyphenol in the peel of an apple is functional to the patties' surface, broiled at $225^{\circ} \mathrm{C}$. The results found by Keşkekoğlu and Üren [35] exposed that the extract of pomegranate seed, added to meatballs of chicken, reduced total HAAs by $49 \%$. Viegas et al. [8] described that marinades comprising white wine, mixed herbs, and beer decreased 4,8-DiMeIQx generation. Fatih $\mathrm{Oz}$ [141] described that the addition of red pepper to meatballs of high-fat decreased the 4,8-DiMeIQx level, with value ranges from 1.77-0.54 ng/g. Moreover, Dong, Lee, and Shin [23] described that marinade added with a sauce of $8 \%$ extracts of water with lotus and olive leaves to fried chicken breasts reduced MeIQx, PhIP and MeIQ formation by $51 \%, 79 \%$, and 23\%, correspondingly. Shin and Ustunol [142] also detected DiMeIQx, PhIP, and MeIQx reduction levels in fried marinated chicken utilizing lemon juice, buckwheat, 
or clover honey. Tengilimoglu-Metin and Kizil [17] exposed that the extract of artichoke, added before cooking, may be effective in limiting the formation of HAAs due to the activities of the antioxidant associated with polyphenolic compounds such as flavonoids and acids.

Vitaglione and Fogliano [136] exposed that tomatoes include carotenoids that can decrease MeIQx and IQ levels in samples of meat by $36 \%$ and $11 \%$, correspondingly, at the $1000 \mathrm{ppm}$ rate. Furthermore, quercetin flavonoid compounds decreased HAAs by up to $67 \%$ at $10 \mathrm{ppm}$ concentration [136]. Rauscher et al. [143] utilized carrot, apricot, tomato, orange, Brussels sprout, peppers, and sprout extracts for the inhibition of HAAs and revealed an antimutagenic capability due to the availability of numerous bioactive components such as carotenoids and xanthophylls. The seeds of corn also comprise anthocyanins that decrease mutagenicity, with PhIP most affected [144]. Similarly, cacao comprises pro-anthocyanides that prevent the effects of carcinogens due to HAAs. The anticancer activity proficiently present in the extract of cherry due to anthocyanins has great potential to decrease the level of HAAs by the action of antioxidative activity [136]. Edenharder et al. [145] reported that grapes, blueberries, spinach, watermelon, parsley, and blackberries decreased HAA concentrations in patties of beef. The inhibitory effect of different plant extracts against various HAAs in meat-based products is presented in Table 2. 
Table 2. Heterocyclic amine inhibitory effect of some plants.

\begin{tabular}{|c|c|c|c|c|c|c|c|c|}
\hline Plant (Part) & Scientific Name & $\begin{array}{c}\text { Extract/Dose } \\
\text { Level }\end{array}$ & Product & Process & Targeted HAAs & $\begin{array}{l}\text { Types of } \\
\text { Inhibitors }\end{array}$ & Inhibition & Reference \\
\hline $\begin{array}{l}\text { Black pepper } \\
\quad(\text { Seed) }\end{array}$ & Piper nigrum & $\begin{array}{c}\text { Powder } \\
1 \%\end{array}$ & Tilapia Fillets & Fried at $180^{\circ} \mathrm{C}$ for $8 \mathrm{~min}$ & PhIP, MelQx & Antioxidants & $\begin{array}{c}\text { PhIP 100\% } \\
\text { MelQx 100\% }\end{array}$ & [146] \\
\hline $\begin{array}{l}\text { Salt cedar } \\
\text { (bark) }\end{array}$ & $\begin{array}{c}\text { Tamarix } \\
\text { ramosissima }\end{array}$ & $\begin{array}{l}60 \% \text { ethanol } \\
0.45 \mathrm{mg} / \mathrm{g}\end{array}$ & Lamb Patties & $\begin{array}{l}\text { Grilled in oven at } 200^{\circ} \mathrm{C} \text { for } \\
20 \mathrm{~min}\end{array}$ & PhIP & Flavonoids & PhIP 72.92\% & [147] \\
\hline $\begin{array}{l}\text { Nutmeg } \\
\text { (Seed) }\end{array}$ & Myristica fragrans & $\begin{array}{c}\text { Essential oil } \\
0.04 \%\end{array}$ & Beef Patties & $\begin{array}{l}\text { Grilled for } 5 \text { min at } 75^{\circ} \mathrm{C} \\
\text { internal temp. }\end{array}$ & MeIQ & Antioxidants & MeIQ 100\% & [148] \\
\hline $\begin{array}{l}\text { yellow gentian } \\
\text { (Leaf) }\end{array}$ & gentiana lutea & $\begin{array}{c}\text { Methanol } \\
2 \%\end{array}$ & Meat & Thermally processed & IQ, PhIP & Antioxidants & $\begin{array}{c}\text { IQ 72\% } \\
\text { PhIP 76\% }\end{array}$ & [150] \\
\hline $\begin{array}{l}\text { yellow gentian } \\
\text { (Root) }\end{array}$ & gentiana lutea & $\begin{array}{c}\text { Methanol } \\
2 \%\end{array}$ & Meat & Thermally processed & IQ, PhIP & Antioxidants & $\begin{array}{l}\text { IQ 58\% } \\
\text { PhIP 80\% }\end{array}$ & [150] \\
\hline $\begin{array}{l}\text { Florist's daisy } \\
\text { (Flower) }\end{array}$ & $\begin{array}{l}\text { Chrysanthemum } \\
\text { morifolium }\end{array}$ & $\begin{array}{c}70 \% \text { Ethanol } \\
0.2 \%\end{array}$ & $\begin{array}{l}\text { Goat Meat } \\
\text { Patties }\end{array}$ & Deep fat fried at $225^{\circ} \mathrm{C}$ & $\begin{array}{l}\text { PhlP, Norharman, } \\
\text { Harman, MelQx }\end{array}$ & $\begin{array}{c}\text { Quercetin } \\
\text { glucoside, } \\
\text { Kaempferol, } \\
\text { Paeoniflorin, } \\
\text { 3-Caffeoylquinic } \\
\text { acid, and } \\
\text { Cyanidin } \\
\text { 3-O-galactoside }\end{array}$ & $\begin{array}{c}\text { PhlP 62\% } \\
\text { Norharman 59\% } \\
\text { Harman 58\% } \\
\text { MelQx 52\% }\end{array}$ & [151] \\
\hline $\begin{array}{l}\text { Turmeric } \\
\text { (Root) }\end{array}$ & Curcuma longa & $\begin{array}{c}80 \% \text { Ethanol } \\
3 \%\end{array}$ & Beef Cubes & $\begin{array}{l}\text { Electrically grilled at } 240^{\circ} \mathrm{C} \\
\text { for } 10 \mathrm{~min}\end{array}$ & $\begin{array}{c}\text { IQ, IQx, 7,8 } \\
\text { DiMeIQx, PhIP, } \\
\text { Harman, } \\
\text { Norharman, A } \alpha \mathrm{C}\end{array}$ & $\begin{array}{l}\text { Curcumin, } \\
\text { Desmethoxycur- } \\
\text { cumin, } \\
\text { Bisdesmethoxy- } \\
\text { curcumin }\end{array}$ & Total HAAs 75.4\% & [33] \\
\hline $\begin{array}{l}\text { Sichuan pepper } \\
\text { (Seed) }\end{array}$ & $\begin{array}{l}\text { Zanthoxylum } \\
\text { bungeanum }\end{array}$ & $\begin{array}{l}\text { Powder } \\
1 \%\end{array}$ & $\begin{array}{l}\text { Grilled Beef } \\
\text { Patties }\end{array}$ & $\begin{array}{l}\text { Powder mixed with beef. } \\
\text { Patties grilled at } 225^{\circ} \mathrm{C} \text { for } \\
10 \mathrm{~min} .\end{array}$ & $\begin{array}{l}\text { PhlP, IQx, MelQx, } \\
\text { 4,8 Di MelQx, }\end{array}$ & $\begin{array}{l}\text { Phenolic } \\
\text { compounds }\end{array}$ & $\begin{array}{c}\text { PhlP 90\% } \\
\text { IQx 100\% } \\
\text { MelQx 81\% } \\
\text { 4,8Di MelQx 89\% }\end{array}$ & [152] \\
\hline
\end{tabular}


Table 2. Cont.

\begin{tabular}{|c|c|c|c|c|c|c|c|c|}
\hline Plant (Part) & Scientific Name & $\begin{array}{c}\text { Extract/Dose } \\
\text { Level }\end{array}$ & Product & Process & Targeted HAAs & $\begin{array}{l}\text { Types of } \\
\text { Inhibitors }\end{array}$ & Inhibition & Reference \\
\hline $\begin{array}{l}\text { Hawthorn } \\
\text { (Fruit, Flower, } \\
\text { Leaves) }\end{array}$ & C. pinnatifida & $\begin{array}{l}\text { Aqueous Extract } \\
\text { Chicken: } 1 \% \\
\text { Beef: } 0.5 \%\end{array}$ & $\begin{array}{l}\text { Chicken } \\
\text { Breasts and } \\
\text { Beef }\end{array}$ & $\begin{array}{l}\text { Pan cooking or oven cooking } \\
\text { at } 150,200 \text {, and } 250{ }^{\circ} \mathrm{C}\end{array}$ & $\begin{array}{c}\text { IQx, IQ, MelQx } \\
\text { MelQ, 4,8 } \\
\text { DiMelQx, 7,8 } \\
\text { DiMelQx, PhlP, } \\
\text { Harman, } \\
\text { Nor-Harman, TrP2 } \\
\end{array}$ & $\begin{array}{l}\text { Flavonoids } \\
\text { Proanthocyanins }\end{array}$ & $\begin{array}{c}\text { Total HAAs } \\
\text { Chicken: 19-97\% } \\
\text { Beef: } \\
42-100 \%\end{array}$ & [140] \\
\hline $\begin{array}{l}\text { Artichoke } \\
\text { (Flower buds) }\end{array}$ & Cynara scolymus & $\begin{array}{l}\text { Commercial } \\
\text { Extract } \\
1 \%\end{array}$ & $\begin{array}{c}\text { Beef and } \\
\text { Chicken Breast }\end{array}$ & $\begin{array}{l}\text { Meat was cooked at 150, 200, } \\
\text { and } 2500^{\circ} \mathrm{C}\end{array}$ & $\begin{array}{c}\text { IQx, IQ, MelQx, } \\
\text { A } \alpha C \\
\text { MelQ, } 4,8 \\
\text { DiMelQx, 7,8 } \\
\text { DiMelQx, PhlP, } \\
\text { Harman, TrP2, } \\
\text { Me } \alpha c \\
\text { Nor-Harman, }\end{array}$ & $\begin{array}{l}\text { Mono- and } \\
\text { di-caffeoylquinic } \\
\text { acids, flavonoids }\end{array}$ & $\begin{array}{c}\text { Total HAAs Beef: } \\
25-98 \% \\
\text { Chicken: } 14-95 \%\end{array}$ & [17] \\
\hline $\begin{array}{c}\text { Clove } \\
\text { (Leaves) }\end{array}$ & $\begin{array}{c}\text { Syzgium } \\
\text { aromaticum }\end{array}$ & $\begin{array}{c}\text { Powder } \\
0.2 \%\end{array}$ & $\begin{array}{l}\text { Barbecued } \\
\text { Sucuk }\end{array}$ & Wire barbecue on charcoal & IQ, MeIQ, MeIQx & Antioxidants & $\begin{array}{c}\text { IQ 41.84\% } \\
\text { MeIQx 53.84\% }\end{array}$ & [76] \\
\hline $\begin{array}{l}\text { Cinnamon } \\
\text { (Leaves) }\end{array}$ & $\begin{array}{l}\text { Cinnamomum } \\
\text { zeylanicum }\end{array}$ & $\begin{array}{l}\text { Powder } \\
0.5 \%\end{array}$ & $\begin{array}{l}\text { Barbecued } \\
\text { Sucuk }\end{array}$ & Wire barbecue on charcoal & $\begin{array}{l}\text { IQ, IQx, MeIQ, } \\
\text { MeIQx }\end{array}$ & Antioxidants & $\begin{array}{c}\text { IQ } 69.50 \% \\
\text { IQx } 25 \% \\
\text { MeIQx } 53.84 \%\end{array}$ & [76] \\
\hline $\begin{array}{l}\text { Apple } \\
\text { (Peel) }\end{array}$ & Malus pumila & $\begin{array}{l}\text { Polyphenol-rich } \\
\text { Extract } \\
0.3 \%\end{array}$ & Beef Patties & $\begin{array}{l}\text { Extract applied on surface at } \\
\text { ambient conditions for } 30 \mathrm{~min} \\
\text { prior to Frying at } 223^{\circ} \mathrm{C} \text { for } \\
10 \text { time. }\end{array}$ & $\begin{array}{l}\text { PhIP, MeIQx, } \\
\text { 4,8-DiMeIQx }\end{array}$ & Proanthocyanidins & $\begin{array}{c}\text { 83\% PhIp } \\
68 \% \text { MeIQx } \\
56 \% \text { 4,8-DiMeIQx }\end{array}$ & [115] \\
\hline $\begin{array}{l}\text { Bamboo } \\
\text { (Leaves) }\end{array}$ & Bambusoideae & $\begin{array}{l}\text { Antioxidant } \\
\text { Mixture } \\
2.5 \mathrm{mg} / \mathrm{mL}\end{array}$ & $\begin{array}{l}\text { Chemical } \\
\text { Model System }\end{array}$ & $\begin{array}{c}2.08 \mathrm{mg} \text { of creatinine and } \\
3.2 \mathrm{mg} \text { of phenylalanine, } \\
\text { weighed and mixed in } 2 \mathrm{~mL} \\
\text { of diethylene glycol }\end{array}$ & $\mathrm{PhIP}$ & $\begin{array}{l}\text { Orientin, } \\
\text { homoorientin, } \\
\text { vitexin, and } \\
\text { isovitex }\end{array}$ & $\mathrm{PhIP}>50 \%$ & [154] \\
\hline
\end{tabular}


Table 2. Cont.

\begin{tabular}{|c|c|c|c|c|c|c|c|c|}
\hline Plant (Part) & Scientific Name & $\begin{array}{c}\text { Extract/Dose } \\
\text { Level }\end{array}$ & Product & Process & Targeted HAAs & $\begin{array}{l}\text { Types of } \\
\text { Inhibitors }\end{array}$ & Inhibition & Reference \\
\hline $\begin{array}{l}\text { Pomegranate } \\
\quad \text { (Seed) }\end{array}$ & Punica granatum & $\begin{array}{l}\text { Commercial } \\
\text { Extract } \\
0.5 \%\end{array}$ & M & Charcoal barbeque & PhIP, IQ, MeIQx & $\begin{array}{c}\text { Phenolic content } \\
\text { and antioxidant } \\
\text { capacity }\end{array}$ & $\begin{array}{l}68 \% \mathrm{PhIP} \\
45 \% \mathrm{IQ} \\
57 \% \mathrm{MeIQx}\end{array}$ & [35] \\
\hline $\begin{array}{l}\text { Pomegranate } \\
\quad \text { (Seed) }\end{array}$ & Punica granatum & $\begin{array}{l}\text { Commercial } \\
\text { Extract } \\
0.5 \%\end{array}$ & $\begin{array}{l}\text { Chicken } \\
\text { meatballs }\end{array}$ & $\begin{array}{c}\text { Oven roasting, charcoal } \\
\text { barbeque, and deep fat frying }\end{array}$ & $\begin{array}{l}\text { PhIP, IQ, MeIQx, } \\
\text { norharman }\end{array}$ & $\begin{array}{c}\text { Phenolic content } \\
\text { and antioxidant } \\
\text { capacity }\end{array}$ & $\begin{array}{c}75 \% \text { PhIP } \\
46 \% \text { IQ } \\
49 \% \text { MeIQx57\% } \\
\text { Nonharman }\end{array}$ & [35] \\
\hline $\begin{array}{l}\text { Grape } \\
\text { (Seed) }\end{array}$ & Vitis vinifera $L$ & $\begin{array}{c}\text { Aqueous Extract } \\
0.6 \%\end{array}$ & Beef Patties & $\begin{array}{l}\text { Marinated patties dispersed } \\
\text { in sunflower oil and fried at } \\
\qquad 230^{\circ} \mathrm{C}\end{array}$ & MelQx, PhlP & $\begin{array}{l}\text { Procyanidins } \\
\text { polyphenols }\end{array}$ & $\begin{array}{l}\text { 70\% MelQx } \\
\text { 90\% PhlP }\end{array}$ & [126] \\
\hline $\begin{array}{l}\text { Savory } \\
\text { (leaves) }\end{array}$ & Satureia hortensis & $\begin{array}{c}\text { Ethanol / Water } \\
(70 / 30 v / v) \\
0.5 \%\end{array}$ & Beef Meat & $\begin{array}{l}\text { Spice extract applied and } \\
\text { cooked meat at } 200{ }^{\circ} \mathrm{C} \text { for } \\
20 \text { min in diethylene glycol }\end{array}$ & PhlP & $\begin{array}{l}\text { Phenolic } \\
\text { compounds }\end{array}$ & PhIP $37.31 \%$ & [39] \\
\hline $\begin{array}{l}\text { Oregano } \\
\text { (leaves) }\end{array}$ & Origanum vulgare & $\begin{array}{c}\text { Ethanol / Water } \\
(70 / 30 v / v) \\
0.2 \%\end{array}$ & Beef Meat & $\begin{array}{l}\text { Spice extract applied and } \\
\text { cooked meat at } 200{ }^{\circ} \mathrm{C} \text { for } \\
20 \text { min in diethylene glycol }\end{array}$ & PhlP & $\begin{array}{l}\text { Phenolic } \\
\text { compounds }\end{array}$ & PhIP $43.28 \%$ & [39] \\
\hline $\begin{array}{l}\text { Black pepper } \\
\quad \text { (Seed) }\end{array}$ & Piper nigrum & $\begin{array}{c}\text { Powder } \\
1 \%\end{array}$ & Meatball & $\begin{array}{l}\text { Black pepper spread on the } \\
\text { surface of meat for } 12 \mathrm{~h} \text { prior } \\
\text { to frying at } 225^{\circ} \mathrm{C}\end{array}$ & $\begin{array}{l}\text { PhIP, MeIQ, } \\
\text { 4,8-DiMeIQx }\end{array}$ & Antioxidants & $\begin{array}{c}100 \% \text { PhIP } \\
\text { Total HAAs } \\
12-100 \%\end{array}$ & {$[55]$} \\
\hline $\begin{array}{l}\text { Rosemary } \\
\text { (Leaves) }\end{array}$ & $\begin{array}{l}\text { Rosmarinus } \\
\text { officinalis }\end{array}$ & $\begin{array}{l}20 \% \text { Ethanol } \\
0.05 \%-0.50 \%\end{array}$ & Beef Patties & $\begin{array}{l}\text { Extract added to ground beef. } \\
\text { Cooking at } 191^{\circ} \mathrm{C} \text { for } 5 \mathrm{~min} .\end{array}$ & MelQx, PhlP & $\begin{array}{l}\text { Rosmarinic acid, } \\
\text { carnosol, carnosic } \\
\text { acid }\end{array}$ & $\begin{array}{l}\text { 91.7\% MelQx } \\
\text { 85.3\% PhlP }\end{array}$ & [155] \\
\hline Hibiscus & Hibiscus sabdariffa & $\begin{array}{c}\text { Commercial } \\
\text { Extract } \\
0.8 \% \\
\end{array}$ & Beef Patties & $\begin{array}{l}\text { Sunflower-oil-coated patties } \\
\text { fried at } 230{ }^{\circ} \mathrm{C}\end{array}$ & MeIQx & $\begin{array}{c}\text { Flavonoids, } \\
\text { anthocyanins }\end{array}$ & $50 \%$ MeIQx & [137] \\
\hline $\begin{array}{l}\text { Green Tea } \\
\text { (Leaves) }\end{array}$ & Camellia sinensis & $\begin{array}{l}\text { Infusion with Hot } \\
\text { Water } \\
10 \mu \mathrm{L} \text { of Standard }\end{array}$ & Pan-Fried Beef & $\begin{array}{c}6 \mathrm{~h} \text { marinated beef grilled at } \\
180-200{ }^{\circ} \mathrm{C} \text { for } 4 \text { min on } \\
\text { each side. }\end{array}$ & PhlP, $\mathrm{A} \alpha \mathrm{C}$ & Catechins & $\begin{array}{l}74 \% \mathrm{PhlP} \\
85 \% \mathrm{~A} \alpha \mathrm{C}\end{array}$ & [156] \\
\hline $\begin{array}{l}\text { Apple } \\
\text { (Fruit) }\end{array}$ & Malus pumila & $\begin{array}{c}\text { Ethanol-Water } \\
\text { extract } \\
0.1 \%\end{array}$ & Beef Patties & $\begin{array}{c}\text { Fried at } 210^{\circ} \mathrm{C} \text { for } 6 \mathrm{~min} \text { on } \\
\text { each side. }\end{array}$ & $\begin{array}{l}\text { PhIP, MeIQx, } \\
\text { 4,8-DiMeIQx }\end{array}$ & $\begin{array}{l}\text { Proanthocyanidins, } \\
\text { phloridzin, and } \\
\text { chlorogenic acid }\end{array}$ & $\begin{array}{c}\text { 69\% PhIp } \\
\text { 59\% MeIQx } \\
\text { 64\% 4,8-DiMeIQx }\end{array}$ & [51] \\
\hline
\end{tabular}


Table 2. Cont.

\begin{tabular}{|c|c|c|c|c|c|c|c|c|}
\hline Plant (Part) & Scientific Name & $\begin{array}{c}\text { Extract/Dose } \\
\text { Level }\end{array}$ & Product & Process & Targeted HAAs & Types of Inhibitors & Inhibition & Reference \\
\hline Elderberry & Sambucus nigra & $\begin{array}{c}\text { Commercial } \\
\text { Extract } \\
0.1 \%\end{array}$ & Beef Patties & $\begin{array}{c}\text { Fried at } 210^{\circ} \mathrm{C} \text { for } 6 \text { min on } \\
\text { each side. }\end{array}$ & $\begin{array}{l}\text { PhIP, MeIQx, } \\
\text { 4,8-DiMeIQx }\end{array}$ & $\begin{array}{l}\text { Phenolic contents } \\
\text { galic acid }\end{array}$ & $\begin{array}{c}\text { 45\% PhIp } \\
\text { Total HAAs 35\% }\end{array}$ & [157] \\
\hline $\begin{array}{c}\text { Pine } \\
\text { (bark extract) }\end{array}$ & Pinus maritima. & $\begin{array}{c}\text { Pycnogenol } \\
\text { Powder } \\
1 \%\end{array}$ & Cooked Beef & Cooked at $200{ }^{\circ} \mathrm{C}$ for $20 \mathrm{~min}$ & $\begin{array}{l}\text { MeIQx, PhIP, } \\
\text { Norharman }\end{array}$ & $\begin{array}{l}\text { Thocyanidins, } \\
\text { catechins, } \\
\text { anthoxanthins, } \\
\text { epicatechins }\end{array}$ & $\begin{array}{c}\text { 77\% MeIQx } \\
54 \% \text { PhIP } \\
\text { 27\% Nonharman }\end{array}$ & [127] \\
\hline $\begin{array}{l}\text { Olive oil } \\
\text { (Fruit) }\end{array}$ & Olea europaea & Frying Oil & Beef Burger & $\begin{array}{l}\text { Fried in fresh virgin olive oil } \\
\text { at } 200^{\circ} \mathrm{C} \text { for } 5 \text { min per side }\end{array}$ & $\begin{array}{l}\text { PhIP, Harman, } \\
\text { Norharman }\end{array}$ & $\begin{array}{l}\text { 3,4-DHPEA-EDA, } \\
\text { 3,4-DHPEA-EA, } \\
\text { p-HPEA-EA, } \\
\text { p-HPEA-EDA, }\end{array}$ & $\begin{array}{c}\text { Total HAAs } \\
40-60 \%\end{array}$ & [158] \\
\hline $\begin{array}{l}\text { Tomato } \\
\text { (Fruit) }\end{array}$ & $\begin{array}{c}\text { Solanum } \\
\text { lycopersicum }\end{array}$ & $\begin{array}{l}\text { Carotenoid } \\
\text { Extract } \\
1000 \mathrm{ppm}\end{array}$ & $\begin{array}{l}\text { Bovine Meat } \\
\text { Juice }\end{array}$ & $\begin{array}{l}\text { Freeze dried meat juice mixed } \\
\text { with water ( } 1: 2 \text { ratio) }\end{array}$ & $\begin{array}{l}\text { MeIQx } \\
\text { 4,8-DiMeIQx }\end{array}$ & $\beta$-carotene, lycopene & $\begin{array}{c}\text { 13\% MeIQx } \\
\text { 5\% 4,8-DiMeIQx }\end{array}$ & [159] \\
\hline $\begin{array}{l}\text { Olive oil } \\
\text { (Fruit) }\end{array}$ & Olea europaea & $\begin{array}{l}\text { Virgin Olive } \\
\text { Oil } \\
500 \mathrm{mg} \text { in } 2.5 \\
\text { mL solution }\end{array}$ & $\begin{array}{c}\text { Chemical } \\
\text { Model System }\end{array}$ & $\begin{array}{l}\text { Creatinine, glycine, and } \\
\text { glucose (1:1:0.5 ration) } \\
\text { dissolved in Milli-Qwater }\end{array}$ & $\begin{array}{c}\text { IQx, MeIQx, } \\
\text { DiMeIQx by 45, 50, } \\
\text { and } 59 \%\end{array}$ & $\begin{array}{l}\text { Phenolic compounds } \\
\text { Dihydroxyphenylethanol } \\
\text { derivatives }\end{array}$ & $\begin{array}{c}45 \% \text { IQx } \\
50 \% \text { MeIQx } \\
59 \% \text { DiMeIQx }\end{array}$ & [160] \\
\hline
\end{tabular}




\section{Suggested Mechanisms for an Inhibitory Effect to Decrease Potential Carcinogenic Constituents}

\subsection{The Action of Antioxidative Products}

Meat products consumed, including processed meat and red meat, may result in the incorporation of possible carcinogenic substances developed by lipid oxidation in the components of meat during cooking. Several studies have confirmed that natural products can cause a reduction in the occurrence of carcinogenic substances developed during meat lipid peroxidation. Natural products that are utilized to reduce the degradation or oxidation of meat components can inhibit the formation of carcinogenic substances after or during cooking, such as the free radicals involved in HAA formation [132].

Vitaglione and Fogliano [136] described that antioxidants could prevent mutagen formation through free radical scavenging and quenching. Antioxidants can reduce the premutagens' biotransformation into reactive species of metabolites by stimulating enzyme detoxification or reactive molecule scavenging activity [136]. Natural products can perform antioxidative activities such as a decrease in oxidative stress or reduction in the oxidation of meat components [161,162].

An antioxidant can protect against the toxicity of iron that chelates ferrous iron and inhibit its reaction with oxygen, peroxides, and chelated iron and trap already developed free radicals. Phenols available in olives rapidly decreased heme-induced peroxidation of lipids and scavenged radicals of (1, 1-diphenyl-2-picrylhydrazyl) DPPH. Vitamin E can inhibit the damage induced by iron, and vitamin $C$ can cause the reduction of free iron into ferrous iron, stimulating the propagation and initiation of free radical reactions [163]. Gobert et al. [164] explained that fruits and vegetables contain polyphenolic extracts that hinder the process of gastric digestion, as revealed through total lipids and contents of heme iron. Consequently, a reduction in heme iron oxidation in products of meat using natural products prevents potential carcinogenic substance formation as meat products are the major source of heme iron [164]. The mechanism of antioxidant activities of natural products is shown in Figure 1.

\subsection{Inhibition of Maillard Reaction}

Several inhibitors have been found in the studies of the Maillard reaction in specific foods [165]. The Maillard reaction is responsible for the possible formation of carcinogenic substances in meat products, and Maillard reaction inhibition is required to reduce the potential carcinogenic substances via the utilization of natural products in the products of meat. The type and concentration of HAAs are closely related to meat type, $\mathrm{pH}$, water activity (aw), and the methods of cooking used, such as grilling, barbecuing, frying, roasting, or baking. The transfer of heat to the meat products' surface and precursors of HAA by mass transport apparent to the meat crust also affect the formation of HAAs [166].

During treatments of heat, the Maillard reaction can decrease HAA formation. Račkauskienè et al. [167] discussed that beetroot (Beta vulgaris) effectively reduced the Maillard reaction's substance formation in meat and milk protein. The spices' role, particularly garlic and onion, as HAA formation inhibitors, has been described [168]. Garlic and onion comprise a high quantity of sulfur compounds, such as thiosulfinates and allicin [166]. Schoch [169] suggested that garlic, containing sulfur compounds such as cystine diallyl disulfide, S-oxides S-alkenyl cysteine, and dipropyl disulfide, possesses an inhibitory impact on HAA formation. The inhibitory impacts of different compounds of sulfur, such as acetylcysteine, cysteine, diallyl disulfide, and glutathione, on MeIQx formation have been shown iin a model system of meat [169]. Maillard reactions are initiated by $\alpha$-dicarbonyls, and polyphenol compounds can hinder Maillard reactions by the trapping of $\alpha$-dicarbonyls. Consequently, we postulate that the trapping of $\alpha$-dicarbonyl and the ability to scavenge of flavonoids or phenolic compounds available in natural products can reduce HAA formation from the Maillard reaction in products of meat. Sugar is a significant factor for decreasing mutagenicity. The content of sugar may be imperative for reducing the formation of mutagens due to the reaction of Maillard [170]. Possible 
mechanism for the inhibition of the formation of potential carcinogenic substances in products of meat by using natural products is described in Figure 2.

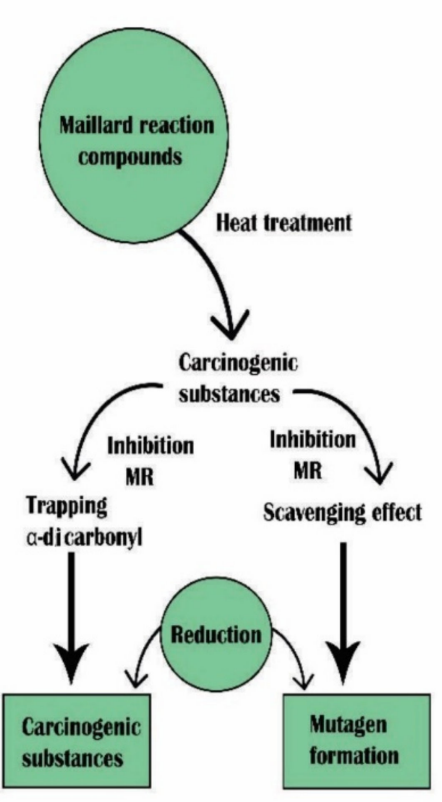

(a) Inhibition of Maillard Reaction

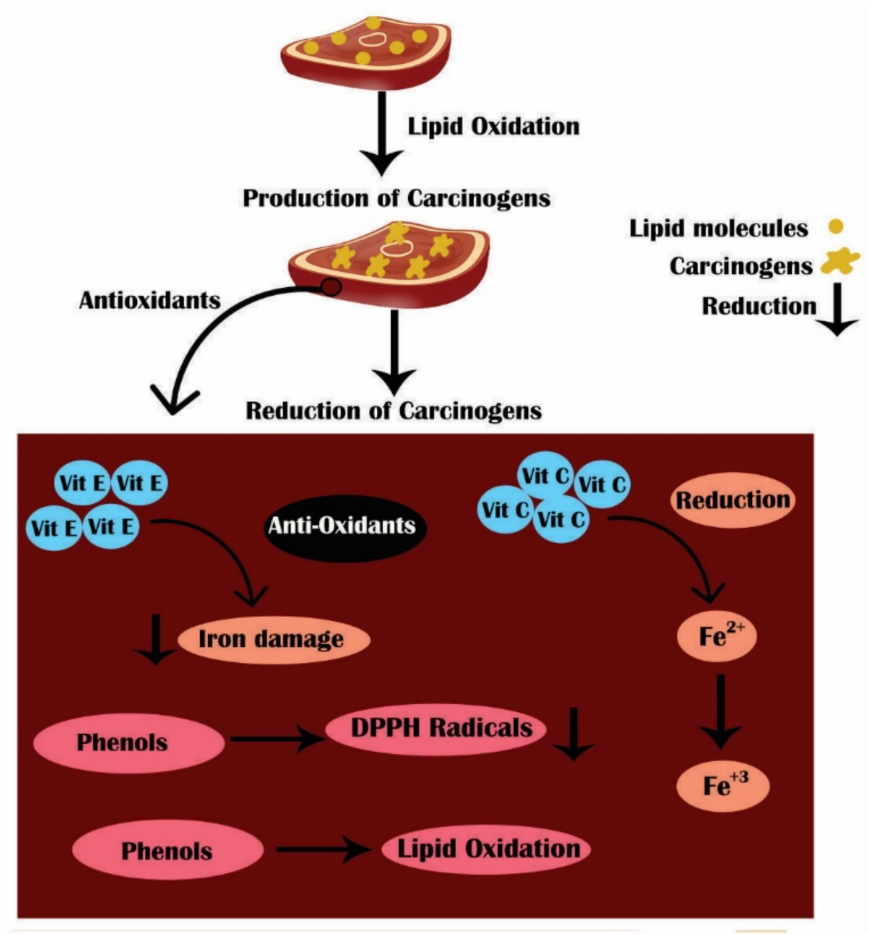

(b) Anti-oxidative Activities

Figure 2. Proposed mechanism of action of natural products on carcinogenic substances. (a) Inhibition of the Maillard reaction; (b) antioxidative activities.

\section{Conclusions}

In conclusion, heterocyclic aromatic amines are potential carcinogens that can lead to a number of different cancer types. Cancer risk is associated with a high intake of well-done cooked meats due to the induction of heterocyclic aromatic amines. Hence, it is necessary to inhibit or minimize the formation of these potent mutagenic and/or carcinogenic HAAs. There are a number of possible means to inhibit the heterocyclic aromatic amines, but, among the different mitigation techniques, the utilization of natural plant extracts containing antioxidants has shown promising inhibitory effects against HAA formation. The studies included in Table 2 of the current study critically articulate the heterocyclic amine inhibitory effect of some plants. For that reason, the addition of plant extracts instead of synthetic antioxidants is recommended before intensive cooking of meat-based products.

Author Contributions: Conceptualization, H.R.N., S.A., T.I. and R.M.A.; writing—original draft preparation, H.R.N., P.S., M.M.A.N.R. and S.A.; writing-review and editing, T.I., J.M.L., L.J. and C.H. All authors have read and agreed to the published version of the manuscript.

Funding: This research received no external funding.

Institutional Review Board Statement: Not applicable.

Informed Consent Statement: Not applicable.

Data Availability Statement: Will be available on request from the corresponding authors.

Acknowledgments: This review article is part of the PhD studies of Hafiz Rehan Nadeem, Institute of Food Science and Nutrition, BZU, Multan, Pakistan. The authors are grateful to GAIN (Axencia Galega de Innovación) for supporting this work (grant number IN607A2019/01). J.M.L. is a member of the Healthy Meat network, funded by CYTED (ref. 119RT0568). 
Conflicts of Interest: The authors declare no conflict of interest.

\section{References}

1. Suleman, R.; Wang, Z.; Aadil, R.M.; Hui, T.; Hopkins, D.L.; Zhang, D. Effect of cooking on the nutritive quality, sensory properties and safety of lamb meat: Current challenges and future prospects. Meat Sci. 2020, 167, 108172. [CrossRef]

2. Gálvez, F.; Domínguez, R.; Pateiro, M.; Carballo, J.; Tomasevic, I.; Lorenzo, J.M. Effect of gender on breast and thigh turkey meat quality. Br. Poult. Sci. 2018, 4, 408-415. [CrossRef]

3. Cadavez, V.A.P.; Popova, T.; Bermúdez, R.; Osoro, K.; Purriños, L.; Bodas, R.; Lorenzo, J.M.; Gonzales-Barron, U. Compositional attributes and fatty acid profile of lamb meat from Iberian local breeds. Small Rumin. Res. 2020. [CrossRef]

4. Lorenzo, J.M.; Maggiolino, A.; Gallego, L.; Pateiro, M.; Serrano, M.P.; Domínguez, R.; García, A.; Landete-Castillejos, T.; De Palo, P. Effect of age on nutritional properties of Iberian wild red deer meat. J. Sci. Food Agric. 2019, 99. [CrossRef]

5. Rahman, U.U.; Sahar, A.; Ishaq, A.; Aadil, R.M.; Zahoor, T.; Ahmad, M.H. Advanced meat preservation methods: A mini review. J. Food Saf. 2018, 38, e12467. [CrossRef]

6. Khan, S.A. The role of pomegranate (Punica granatum L.) in colon cancer. Short communication. Pak. J. Pharm. Sci. 2009, 22, 346-348. [PubMed]

7. Hasnol, N.D.S.; Jinap, S.; Sanny, M. Effect of different types of sugars in a marinating formulation on the formation of heterocyclic amines in grilled chicken. Food Chem. 2014, 145, 514-521. [CrossRef] [PubMed]

8. Viegas, O.; Amaro, L.F.; Ferreira, I.M.P.L.V.O.; Pinho, O. Inhibitory effect of antioxidant-rich marinades on the formation of heterocyclic aromatic amines in pan-fried beef. J. Agric. Food Chem. 2012, 60, 6235-6240. [CrossRef]

9. Szterk, A.; Jesionkowska, K. Influence of the cold storage time of raw beef meat and grilling parameters on sensory quality and content of heterocyclic aromatic amines. LWT Food Sci. Technol. 2015, 61, 299-308. [CrossRef]

10. Domínguez, R.; Gómez, M.; Fonseca, S.; Lorenzo, J.M. Effect of different cooking methods on lipid oxidation and formation of volatile compounds in foal meat. Meat Sci. 2014, 97, 223-230. [CrossRef]

11. Vichapong, J.; Burakham, R.; Srijaranai, S. Air-agitated cloud-point extraction coupled with high-performance liquid chromatography for determination of heterocyclic aromatic amines in smoked sausages. Food Anal. Methods 2017, 10, 1645-1652. [CrossRef]

12. Chen, J.; He, Z.; Qin, F.; Chen, J.; Zeng, M. Formation of free and protein-bound heterocyclic amines in roast beef patties assessed by UPLC-MS/MS. J. Agric. Food Chem. 2017, 65, 4493-4499. [CrossRef]

13. Boskovic, M.; Baltic, M. Association between red meat consumption and cancer risk. Sci. J. Meat Technol. 2017, 57, 81-88.

14. Barzegar, F.; Kamankesh, M.; Mohammadi, A. Heterocyclic aromatic amines in cooked food: A review on formation, health risk-toxicology and their analytical techniques. Food Chem. 2019, 280, 240-254. [CrossRef] [PubMed]

15. Puangsombat, K.; Gadgil, P.; Houser, T.A.; Hunt, M.C.; Smith, J.S. Heterocyclic amine content in commercial ready to eat meat products. Meat Sci. 2011, 88, 227-233. [CrossRef] [PubMed]

16. Hou, C.; Wang, Z.; Wu, L.; Chai, J.; Song, X.; Wang, W.; Zhang, D. Effects of breeds on the formation of heterocyclic aromatic amines in smoked lamb. Int. J. Food Sci. Technol. 2017, 52, 2661-2669. [CrossRef]

17. Tengilimoglu-Metin, M.M.; Kizil, M. Reducing effect of artichoke extract on heterocyclic aromatic amine formation in beef and chicken breast meat. Meat Sci. 2017, 134, 68-75. [CrossRef]

18. Gibis, M. Heterocyclic aromatic amines in cooked meat products: causes, formation, occurrence, and risk assessment. Compr. Rev. Food Sci. Food Saf. 2016, 15, 269-302. [CrossRef] [PubMed]

19. Zhang, W.Y.; Lee, J.J.; Kim, Y.; Kim, I.S.; Han, J.H.; Lee, S.G.; Ahn, M.J.; Jung, S.H.; Myung, C.S. Effect of eriodictyol on glucose uptake and insulin resistance in vitro. J. Agric. Food Chem. 2012, 60, 7652-7658. [CrossRef]

20. Lippi, G.; Mattiuzzi, C.; Cervellin, G. Meat consumption and cancer risk: A critical review of published meta-analyses. Crit. Rev. Oncol. Hematol. 2016, 97, 1-14. [CrossRef] [PubMed]

21. Sanz Alaejos, M.; Ayala, J.H.; González, V.; Afonso, A.M. Analytical methods applied to the determination of heterocyclic aromatic amines in foods. J. Chromatogr. B Anal. Technol. Biomed. Life Sci. 2008, 862, 15-42. [CrossRef] [PubMed]

22. Bouvard, V.; Loomis, D.; Guyton, K.Z.; Grosse, Y.; El Ghissassi, F.; Benbrahim-Tallaa, L.; Guha, N.; Mattock, H.; Straif, K.; Stewart, B.W.; et al. Carcinogenicity of consumption of red and processed meat. Lancet Oncol. 2015, 16, 1599-1600. [CrossRef]

23. Dong, A.; Lee, J.; Shin, H.S. Influence of natural food ingredients on the formation of heterocyclic amines in fried beef patties and chicken breasts. Food Sci. Biotechnol. 2011, 20, 359-365. [CrossRef]

24. Lu, F.; Kuhnle, G.K.; Cheng, Q. The effect of common spices and meat type on the formation of heterocyclic amines and polycyclic aromatic hydrocarbons in deep-fried meatballs. Food Control. 2018, 92, 399-411. [CrossRef]

25. Zeng, M.; He, Z.; Zheng, Z.; Qin, F.; Tao, G.; Zhang, S.; Gao, Y.; Chen, J. Effect of six chinese spices on heterocyclic amine profiles in roast beef patties by ultra performance liquid chromatography-tandem mass spectrometry and principal component analysis. J. Agric. Food Chem. 2014, 62, 9908-9915. [CrossRef] [PubMed]

26. Ranjha, M.M.A.N.; Irfan, S.; Nadeem, M.; Mahmood, S. A comprehensive review on nutritional value, medicinal uses, and processing of banana. Food Rev. Int. 2020. [CrossRef]

27. Ranjha, M.M.A.N.; Amjad, S.; Ashraf, S.; Khawar, L.; Safdar, M.N.; Jabbar, S.; Nadeem, M.; Mahmood, S.; Murtaza, M.A. Extraction of polyphenols from apple and pomegranate peels employing different extraction techniques for the development of functional date bars. Int. J. Fruit Sci. 2020, 20, 1201-1221. [CrossRef] 
28. Shehzadi, K.; Rubab, Q.; Asad, L.; Ishfaq, M.; Shafique, B.; Modassar, M.; Ranjha, A.N.; Mahmood, S.; Mueen-Ud-Din, G.; Javaid, T.; et al. A critical review on presence of polyphenols in commercial varieties of apple peel, their extraction and Health benefits. Open Access J. Biog. Sci. Res. 2020, 6. [CrossRef]

29. Sabtain, B.; Farooq, R.; Shafique, B.; Modassar, M.; Ranjha, A.N. A narrative review on the phytochemistry, nutritional profile and properties of prickly pear fruit. Open Access J. Biog. Sci. Res. 2021, 7. [CrossRef]

30. Oz, F.; Zikirov, E. The effects of sous-vide cooking method on the formation of heterocyclic aromatic amines in beef chops. LWT Food Sci. Technol. 2015, 64, 120-125. [CrossRef]

31. Irfan, S.; Ranjha, M.M.A.N.; Mahmood, S.; Saeed, W.; Alam, M.Q. Lemon peel: A natural medicine. Int. J. Biotechnol. Allied Fields 2018, 7, 185-194.

32. Irfan, S.; Ranjha, M.M.A.N.; Mahmood, S.; Mueen-ud-Din, G.; Rehman, S.; Saeed, W.; Qamrosh Alam, M.; Mahvish Zahra, S.; Yousaf Quddoos, M.; Ramzan, I.; et al. A critical review on pharmaceutical and medicinal importance of ginger. Acta Sci. Nutr. Health 2019, 3, 78-82.

33. Sepahpour, S.; Selamat, J.; Khatib, A.; Manap, M.Y.A.; Abdull Razis, A.F.; Hajeb, P. Inhibitory effect of mixture herbs/spices on formation of heterocyclic amines and mutagenic activity of grilled beef. Food Addit. Contam. Part A Chem. Anal. Control. Expo. Risk Assess. 2018, 35, 1911-1927. [CrossRef]

34. Ranjha, M.M.A.N.; Shafique, B.; Wang, L.; Irfan, S.; Safdar, M.N.; Murtaza, M.A.; Nadeem, M.; Mahmood, S.; Mueen-ud-Din, G.; Nadeem, H.R. A comprehensive review on phytochemistry, bioactivity and medicinal value of bioactive compounds of pomegranate (Punica granatum). Adv. Tradit. Med. 2021. [CrossRef]

35. Keşkekoğlu, H.; Üren, A. Inhibitory effects of pomegranate seed extract on the formation of heterocyclic aromatic amines in beef and chicken meatballs after cooking by four different methods. Meat Sci. 2014, 96, 1446-1451. [CrossRef]

36. Natale, D.; Gibis, M.; Rodriguez-Estrada, M.T.; Weiss, J. Inhibitory effect of liposomal solutions of grape seed extract on the formation of heterocyclic aromatic amines. J. Agric. Food Chem. 2014, 62, 279-287. [CrossRef] [PubMed]

37. Rounds, L.; Havens, C.M.; Feinstein, Y.; Friedman, M.; Ravishankar, S. Concentration-dependent inhibition of Escherichia coli O157: H7 and heterocyclic amines in heated ground beef patties by apple and olive extracts, onion powder and clove bud oil. Meat Sci. 2013, 94, 461-467. [CrossRef]

38. Jinap, S.; Iqbal, S.Z.; Selvam, R.M.P. Effect of selected local spices marinades on the reduction ofheterocyclic amines in grilled beef (satay). LWT Food Sci. Technol. 2015, 63, 919-926. [CrossRef]

39. Damašius, J.; Venskutonis, P.R.; Ferracane, R.; Fogliano, V. Assessment of the influence of some spice extracts on the formation of heterocyclic amines in meat. Food Chem. 2011, 126, 149-156. [CrossRef]

40. Ruan, E.D.; Juárez, M.; Thacker, R.; Yang, X.; Dugan, M.E.R.; Aalhus, J.L. Dietary vitamin E effects on the formation of heterocyclic amines in grilled lean beef. Meat Sci. 2014, 96, 849-853. [CrossRef]

41. Wong, D.; Cheng, K.W.; Wang, M. Inhibition of heterocyclic amine formation by water-soluble vitamins in Maillard reaction model systems and beef patties. Food Chem. 2012, 133, 760-766. [CrossRef]

42. Szterk, A.; Waszkiewicz-Robak, B. Influence of selected quality factors of beef on the profile and the quantity of heterocyclic aromatic amines during processing at high temperature. Meat Sci. 2014, 96, 1177-1184. [CrossRef]

43. Xian, Y.; Wu, Y.; Dong, H.; Chen, L.; Zhang, C.; Hou, X.; Zeng, X.; Bai, W.; Guo, X. Modified QuEChERS purification and $\mathrm{Fe}_{3} \mathrm{O}_{4}$ nanoparticle decoloration for robust analysis of 14 heterocyclic aromatic amines and acrylamide in coffee products using UHPLC-MS/MS. Food Chem. 2019, 285, 77-85. [CrossRef] [PubMed]

44. Szterk, A.; Roszko, M.; Cybulski, A. Determination of azaarenes in oils using the LC-APCI-MS/MS technique: New environmental toxicant in food oils. J. Sep. Sci. 2012, 35, 2858-2865. [CrossRef]

45. Casal, S.; Mendes, E.; Fernandes, J.O.; Oliveira, M.B.P.P.; Ferreira, M.A. Analysis of heterocyclic aromatic amines in foods by gas chromatography-mass spectrometry as their tert.-butyldimethylsilyl derivatives. J. Chromatogr. A 2004, 1040, 105-114. [CrossRef] [PubMed]

46. Solyakov, A.; Skog, K. Screening for heterocyclic amines in chicken cooked in various ways. Food Chem. Toxicol. 2002, 40, 1205-1211. [CrossRef]

47. Puangsombat, K.; Gadgil, P.; Houser, T.A.; Hunt, M.C.; Smith, J.S. Occurrence of heterocyclic amines in cooked meat products. Meat Sci. 2012, 90, 739-746. [CrossRef]

48. Gibis, M.; Weiss, J. Impact of precursors creatine, creatinine, and glucose on the formation of heterocyclic aromatic amines in grilled patties of various animal species. J. Food Sci. 2015, 80, C2430-C2439. [CrossRef] [PubMed]

49. Gibis, M.; Loeffler, M. Effect of creatine and glucose on formation of heterocyclic amines in grilled chicken breasts. Foods 2019, 8, 616. [CrossRef]

50. Račkauskienè, I.; Pukalskas, A.; Fiore, A.; Troise, A.D.; Venskutonis, P.R. Phytochemical-rich antioxidant extracts of Vaccinium Vitis-idaea L. leaves inhibit the formation of toxic maillard reaction products in food models. J. Food Sci. 2019, 84, $3494-3503$. [CrossRef]

51. Cheng, K.W.; Wu, Q.; Zong, P.Z.; Peng, X.; Simon, J.E.; Chen, F.; Wang, M. Inhibitory effect of fruit extracts on the formation of heterocyclic amines. J. Agric. Food Chem. 2007, 55, 10359-10365. [CrossRef] [PubMed]

52. Zöchling, S.; Murkovic, M. Formation of the heterocyclic aromatic amine PhIP: Identification of precursors and intermediates. Food Chem. 2002, 79, 125-134. [CrossRef] 
53. Jinap, S.; Mohd-Mokhtar, M.S.; Farhadian, A.; Hasnol, N.D.S.; Jaafar, S.N.; Hajeb, P. Effects of varying degrees of doneness on the formation of heterocyclic aromatic amines in chicken and beef satay. Meat Sci. 2013, 94, 202-207. [CrossRef]

54. Oz, F.; Kizil, M.; Zaman, A.; Turhan, S. The effects of direct addition of low and medium molecular weight chitosan on the formation of heterocyclic aromatic amines in beef chop. LWT Food Sci. Technol. 2016, 65, 861-867. [CrossRef]

55. Oz, F.; Kaban, G.; Kaya, M. Effects of cooking methods and levels on formation of heterocyclic aromatic amines in chicken and fish with Oasis extraction method. LWT Food Sci. Technol. 2010, 43, 1345-1350. [CrossRef]

56. Polak, M.L.; Demšar, L.; Zahija, I.; Polak, T. Influence of temperature on the formation of heterocyclic aromatic amines in pork steaks. Czech. J. Food Sci. 2020, 38, 248-254. [CrossRef]

57. Knize, M.G.; Dolbeare, F.A.; Carroll, K.L.; Moore, D.H.; Felton, J.S. Effect of cooking time and temperature on the heterocyclic amine content of fried beef patties. Food Chem. Toxicol. 1994, 32, 595-603. [CrossRef]

58. Knize, M.G.; Salmon, C.P.; Mehta, S.S.; Felton, J.S. Analysis of cooked muscle meats for heterocyclic aromatic amine carcinogens. Mutat. Res. Fundam. Mol. Mech. Mutagen. 1997, 376, 129-134. [CrossRef]

59. Janoszka, B. Heterocyclic amines and azaarenes in pan-fried meat and its gravy fried without additives and in the presence of onion and garlic. Food Chem. 2010, 120, 463-473. [CrossRef]

60. Alaejos, M.S.; Afonso, A.M. Factors that affect the content of heterocyclic aromatic amines in foods. Compr. Rev. Food Sci. Food Saf. 2011, 10, 52-108. [CrossRef]

61. Bordas, M.; Moyano, E.; Puignou, L.; Galceran, M.T. Formation and stability of heterocyclic amines in a meat flavour model system: Effect of temperature, time and precursors. J. Chromatogr. B Anal. Technol. Biomed. Life Sci. 2004, 802, 11-17. [CrossRef] [PubMed]

62. Tai, C.Y.; Lee, K.H.; Chen, B.H. Effects of various additives on the formation of heterocyclic amines in fried fish fibre. Food Chem. 2001, 75, 309-316. [CrossRef]

63. Wu, M.C.; Ma, C.Y.; Yang, C.C.; Kao, W.C.; Shen, S.C. The formation of IQ type mutagens from Maillard reaction in ethanolic solution. Food Chem. 2011, 125, 582-587. [CrossRef]

64. Jung, K.; Lee, K.; Park, J.; Dong, A.; Shin, H.S. Influence of fructooligosaccharides and garlic on formation of heterocyclic amines in fried ground beef patties. Food Sci. Biotechnol. 2010, 19, 1159-1164. [CrossRef]

65. Liao, G.Z.; Wang, G.Y.; Xu, X.L.; Zhou, G.H. Effect of cooking methods on the formation of heterocyclic aromatic amines in chicken and duck breast. Meat Sci. 2010, 85, 149-154. [CrossRef] [PubMed]

66. Skog, K. Problems associated with the determination of heterocyclic amines in cooked foods and human exposure. Food Chem. Toxicol. 2002, 40, 1197-1203. [CrossRef]

67. Kizil, M.; Oz, F.; Besler, H.T. A review on the formation of carcinogenic/mutagenic heterocyclic aromatic amines. J. Food Process. Technol. 2011, 02, 2-5. [CrossRef]

68. Özdestan, Ö.; Kaçar, E.; Keşkekoğlu, H.; Üren, A. Development of a new extraction method for heterocyclic aromatic amines determination in cooked meatballs. Food Anal. Methods 2014, 7, 116-126. [CrossRef]

69. Murkovic, M. Chemistry, formation and occurrence of genotoxic heterocyclic aromatic amines in fried products. Eur. J. Lipid Sci. Technol. 2004, 106, 777-785. [CrossRef]

70. Yu, D.; Chen, M.; Yu, S. Effect of sugarcane molasses extract on the formation of 2-amino-1- methyl-6-phenylimidazo (4, 5-b] pyridine (PhIP) in a model system. Food Chem. 2016, 197, 924-929. [CrossRef]

71. Karpavičiūte, D.; Murkovic, M.; Vinauskiene, R.; Venskutonis, R. Determination of non-polar heterocyclic aromatic amines in roasted coffee by SPE-HPLC-FLD. Chem. Pap. 2017, 71, 67-70. [CrossRef]

72. Sahar, A.; Portanguen, S.; Kondjoyan, A.; Dufour, E. Potential of synchronous fluorescence spectroscopy coupled with chemometrics to determine the heterocyclic aromatic amines in grilled meat. Eur. Food Res. Technol. 2010, 231, 803-812. [CrossRef]

73. Balogh, Z.; Gray, J.I.; Gomaa, E.A.; Booren, A.M. Formation and inhibition of heterocyclic aromatic amines in fried ground beef patties. Food Chem. Toxicol. 2000, 38, 395-401. [CrossRef]

74. Oz, F.; Kotan, G. Effects of different cooking methods and fat levels on the formation of heterocyclic aromatic amines in various fishes. Food Control 2016, 67, 216-224. [CrossRef]

75. Unal, K.; Karakaya, M.; Oz, F. The effects of different spices and fat types on the formation of heterocyclic aromatic amines in barbecued sucuk. J. Sci. Food Agric. 2018, 98, 719-725. [CrossRef] [PubMed]

76. Raza, A.; Shabbir, M.A.; Khan, M.I.; Suleria, H.A.R.; Sultan, S. Effect of Thermal Treatments on the Formation of Heterocyclic Aromatic Amines in Various Meats. J. Food Process. Preserv. 2015, 39, 376-383. [CrossRef]

77. Haskaraca, G.; Demirok, E.; Kolsarici, N.; Öz, F.; Özsaraç, N. Effect of green tea extract and microwave pre-cooking on the formation of heterocyclic aromatic amines in fried chicken meat products. Food Res. Int. 2014, 63, 373-381. [CrossRef]

78. Aeenehvand, S.; Toudehrousta, Z.; Kamankesh, M.; Mashayekh, M.; Tavakoli, H.R.; Mohammadi, A. Evaluation and application of microwave-assisted extraction and dispersive liquid-liquid microextraction followed by high-performance liquid chromatography for the determination of polar heterocyclic aromatic amines in hamburger patties. Food Chem. 2016, 190, 429-435. [CrossRef]

79. Richling, E.; Decker, C.; Häring, D.; Herderich, M.; Schreier, P. Analysis of heterocyclic aromatic amines in wine by highperformance liquid chromatography-electrospray tandem mass spectrometry. J. Chromatogr. A 1997, 791, 71-77. [CrossRef]

80. Krach, C.; Sontag, G. Determination of some heterocyclic aromatic amines in soup cubes by ion-pair chromatography with coulometric electrode array detection. Anal. Chim. Acta 2000, 417, 77-83. [CrossRef] 
81. Stavric, B.; Lau, B.P.Y.; Matula, T.I.; Klassen, R.; Lewis, D.; Downie, R.H. Mutagenic heterocyclic aromatic amines (HAAs) in "processed food flavour" samples. Food Chem. Toxicol. 1997, 35, 185-197. [CrossRef]

82. Khan, M.R.; Naushad, M.; Alothman, Z.A.; Alsohaimi, I.H.; Algamdi, M.S. Solid phase extraction and ultra performance liquid chromatography-tandem mass spectrometric identification of carcinogenic/mutagenic heterocyclic amines in cooked camel meat. RSC Adv. 2015, 5, 2479-2485. [CrossRef]

83. Gross, G.A.; Turesky, R.J.; Fay, L.B.; Stillwell, W.G.; Skipper, P.L.; Tannenbaum, S.R. Heterocyclic aromatic amine formation in grilled bacon, beef and fish and in grill scrapings. Carcinogenesis 1993, 14, 2313-2318. [CrossRef]

84. Ni, W.; McNaughton, L.; LeMaster, D.M.; Sinha, R.; Turesky, R.J. Quantitation of 13 heterocyclic aromatic amines in cooked beef, pork, and chicken by liquid chromatography-electrospray ionization/tandem mass spectrometry. J. Agric. Food Chem. 2008, 56, 68-78. [CrossRef]

85. Turesky, R.J.; Taylor, J.; Schnackenberg, L.; Freeman, J.P.; Holland, R.D. Quantitation of carcinogenic heterocyclic aromatic amines and detection of novel heterocyclic aromatic amines in cooked meats and grill scrappings by HPLC/ESI-MS. J. Agric. Food Chem. 2005, 53, 3248-3258. [CrossRef]

86. Gibis, M.; Kruwinnus, M.; Weiss, J. Impact of different pan-frying conditions on the formation of heterocyclic aromatic amines and sensory quality in fried bacon. Food Chem. 2015, 168, 383-389. [CrossRef]

87. Naccari, C.; Galceran, M.T.; Moyano, E.; Cristani, M.; Siracusa, L.; Trombetta, D. Presence of heterocyclic aromatic amines (HAS) in smoked "Provola" cheese from Calabria (Italy). Food Chem. Toxicol. 2009, 47, 321-327. [CrossRef] [PubMed]

88. Yang, Z.; Lu, R.U.I.; Song, H.; Zhang, Y.U.; Tang, J.; Zhou, N. Effect of different cooking methods on the formation of aroma components and heterocyclic amines in pork loin. J. Food Process. Preserv. 2016, 1-8. [CrossRef]

89. Busquets, R.; Puignou, L.; Galceran, M.T.; Wakabayashi, K.; Skog, K. Liquid chromatography-tandem mass spectrometry analysis of 2-amino-1-methyl-6-(4-hydroxyphenyl)imidazo[4,5-b]pyridine in cooked meats. J. Agric. Food Chem. 2007, 55, 9318-9324. [CrossRef]

90. Becher, G.; Knize, M.G.; Nes, I.F.; Felton, J.S. Isolation and identification of mutagens from a fried norwegian meat product. Carcinogenesis 1988, 9, 247-253. [CrossRef] [PubMed]

91. Zou, X.; Yan, C.; Shi, Y.; Cao, K.; Xu, J.; Wang, X.; Chen, C.; Luo, C.; Li, Y.; Gao, J.; et al. Mitochondrial dysfunction in obesity-associated nonalcoholic fatty liver disease: The protective effects of pomegranate with its active component punicalagin. Antioxidants Redox Signal. 2014, 21, 1557-1570. [CrossRef]

92. Martín-Calero, A.; Pino, V.; Ayala, J.H.; González, V.; Afonso, A.M. Ionic liquids as mobile phase additives in high-performance liquid chromatography with electrochemical detection: Application to the determination of heterocyclic aromatic amines in meat-based infant foods. Talanta 2009, 79, 590-597. [CrossRef]

93. Herraiz, T. Identification and occurence of the bioactive $\beta$-carbolines norharman and harman in coffee brews. Food Addit. Contam. 2002, 19, 748-754. [CrossRef] [PubMed]

94. Szterk, A. Heterocyclic aromatic amines in grilled beef: The influence of free amino acids, nitrogenous bases, nucleosides, protein and glucose on HAAs content. J. Food Compos. Anal. 2015, 40, 39-46. [CrossRef]

95. Gross, G.A.; Grüter, A.; Heyland, S. Optimization of the sensitivity of high-performance liquid chromatography in the detection of heterocyclic aromatic amine mutagens. Food Chem. Toxicol. 1992, 30, 491-498. [CrossRef]

96. Costa, M.; Viegas, O.; Melo, A.; Petisca, C.; Pinho, O.; Ferreira, I.M.P.L. Heterocyclic aromatic amine formation in barbecued sardines (sardina pilchardus) and atlantic salmon (salmo salar). J. Agric. Food Chem. 2009, 57, 3173-3179. [CrossRef]

97. Sentellas, S.; Moyano, E.; Puignuo, L.; Galceran, M.T. Determination of heterocyclic aromatic amines by capillary electrophoresis coupled to mass spectrometry using in-line preconcentration. Electrophoresis 2003, 24, 3075-3082. [CrossRef]

98. Yan, A.Y.; Zhang, S.; Tao, G. Acetonitrile extraction coupled with UHPLC-MS/MS for the accurate quantification of 17-heterocyclic aromatic amines in meat products. J. Chromatogr. B 2017, 10, 1-25. [CrossRef]

99. Feng, Z.; Quan-Fu, L.; Xiao-Gang, C.; Jing, L.; Li, S.; Yun, L.; Cheng-Bao, X. Simultaneous determination of 15 heterocyclic amines in grilled fish using solid phase extraction and ultra performance liquid chromatography with electrospray ionization tandem mass spectrometry. Chin. J. Anal. Chem. 2011, 39, 501-505.

100. Lee, J.; Dong, A.; Jung, K.; Shin, H.S. Influence of extra virgin olive oil on the formation of heterocyclic amines in roasted beef steak. Food Sci. Biotechnol. 2011, 20, 159-165. [CrossRef]

101. Zaidi, R.; Rani Rawat, P. Identification of heterocyclic amines in Indian home cooked and commercially available meat foods. J. Nutr. Food Sci. 2011, 1. [CrossRef]

102. Jautz, U.; Gibis, M.; Morlock, G.E. Quantification of heterocyclic aromatic amines in fried meat by HPTLC/UV-FLD and HPLC/UV-FLD: A comparison of two methods. J. Agric. Food Chem. 2008, 56, 4311-4319. [CrossRef]

103. Vanderlaan, M.; Watkins, B.E.; Hwang, M.; Kinze, M.G.; Felton, J.S. Monoclonal antibodies to 2-amino-1-methyl-6phenylimidazo[4,5-b] pyridine (PhIP) and their use in the analysis of well-done fried beef. Carcinogenesis 1989, 10, $2215-2221$. [CrossRef]

104. Roemer, E.; Meisgen, T.; Diekmann, J.; Conroy, L.; Stabbert, R. Heterocyclic aromatic amines and their contribution to the bacterial mutagenicity of the particulate phase of cigarette smoke. Toxicol. Lett. 2016, 243, 40-47. [CrossRef] [PubMed]

105. Sugimura, T.; Wakabayashi, K.; Nakagama, H.; Nagao, M. Heterocyclic amines: Mutagens/carcinogens produced during cooking of meat and fish. Gann Monogr. Cancer Res. 2004, 52, 71-96. [CrossRef] [PubMed]

106. Püssa, T. Toxicological issues associated with production and processing of meat. Meat Sci. 2013, 95, 844-853. [CrossRef] 
107. Lynch, A.M.; Murray, S.; Gooderham, N.J.; Boobis, A.R. Exposure to and activation of dietary heterocyclic amines in humans. Crit. Rev. Oncol. Hematol. 1995, 21, 19-31. [CrossRef]

108. Sasaki, J.C.; Fellers, R.S.; Colvin, M.E. Metabolic oxidation of carcinogenic arylamines by P450 monooxygenases: Theoretical support for the one-electron transfer mechanism. Mutat. Res. Fundam. Mol. Mech. Mutagen. 2002, 506-507, 79-89. [CrossRef]

109. Turesky, R.J.; Le Marchand, L. Metabolism and biomarkers of heterocyclic aromatic amines in molecular epidemiology studies: Lessons learned from aromatic amines. Chem. Res. Toxicol. 2011, 24, 1169-1214. [CrossRef]

110. Bogen, K.T.; Keating, G.A. U.S. dietary exposures to heterocyclic amines. J. Expo. Anal. Environ. Epidemiol. 2001, 11, 155-168. [CrossRef]

111. Skog, K.; Solyakov, A.; Jägerstad, M. Effects of heating conditions and additives on the formation of heterocyclic amines with reference to amino-carbolines in a meat juice model system. Food Chem. 2000, 68, 299-308. [CrossRef]

112. Sinha, R.; Rothman, N.; Salmon, C.P.; Mark, S.D.; Brown, E.D.; Levander, O.A.; Knize, M.G.; Swanson, C.A.; Felton, J.S.; Rossi, S.C. High concentrations of the carcinogen 2-amino-1-methyl-6-phenylimidazo-[4,5-b]pyridine (phip) occur in chicken but are dependent on the cooking method. Cancer Res. 1995, 55, 4516-4519.

113. Wolk, A. Potential health hazards of eating red meat. J. Intern. Med. 2017, 281, 106-122. [CrossRef] [PubMed]

114. Sabally, K.; Sleno, L.; Jauffrit, J.A.; Iskandar, M.M.; Kubow, S. Inhibitory effects of apple peel polyphenol extract on the formation of heterocyclic amines in pan fried beef patties. Meat Sci. 2016, 117, 57-62. [CrossRef]

115. Rohrmann, S.; Hermann, S.; Linseisen, J. Heterocyclic aromatic amine intake increases colorectal adenoma risk: Findings from a prospective European cohort study. Am. J. Clin. Nutr. 2009, 89, 1418-1424. [CrossRef]

116. Szterk, A. Chemical state of heterocyclic aromatic amines in grilled beef: Evaluation by in vitro digestion model and comparison of alkaline hydrolysis and organic solvent for extraction. Food Chem. Toxicol. 2013, 62, 653-660. [CrossRef]

117. Oba, S.; Shimizu, N.; Nagata, C.; Shimizu, H.; Kametani, M.; Takeyama, N.; Ohnuma, T.; Matsushita, S. The relationship between the consumption of meat, fat, and coffee and the risk of colon cancer: A prospective study in Japan. Cancer Lett. 2006, 244, 260-267. [CrossRef] [PubMed]

118. Namiranian, N.; Moradi-Lakeh, M.; Razavi-Ratki, S.K.; Doayie, M.; Nojomi, M. Risk factors of breast cancer in the eastern mediterranean region: A systematic review and meta-analysis. Asian Pac. J. Cancer Prev. 2014, 15, 9535-9541. [CrossRef] [PubMed]

119. Paluszkiewicz, P.; Smolińska, K.; Debińska, I.; Turski, W.A. Main dietary compounds and pancreatic cancer risk. The quantitative analysis of case-control and cohort studies. Cancer Epidemiol. 2012, 36, 60-67. [CrossRef] [PubMed]

120. Smolińska, K.; Paluszkiewicz, P. Risk of colorectal cancer in relation to frequency and total amount of red meat consumption. Systematic review and meta-analysis. Arch. Med. Sci. 2010, 6, 605-610. [CrossRef]

121. Puangsombat, K.; Jirapakkul, W.; Smith, J.S. Inhibitory activity of Asian spices on heterocyclic amines formation in cooked beef patties. J. Food Sci. 2011, 76, 174-180. [CrossRef]

122. Lim, W.Y.; Chuah, K.L.; Eng, P.; Leong, S.S.; Lim, E.; Lim, T.K.; Ng, A.; Poh, W.T.; Tee, A.; Teh, M.; et al. Meat consumption and risk of lung cancer among never-smoking women. Nutr. Cancer 2011, 63, 850-859. [CrossRef]

123. Miyazawa, M.; Okuno, Y.; Imanishi, K. Suppression of the SOS-inducing activity of mutagenic heterocyclic amine, Trp-P-1, by triterpenoid from Uncaria sinensis in the Salmonella typhimurium TA1535/pSK1002 umu test. J. Agric. Food Chem. 2005, 53, 2312-2315. [CrossRef]

124. Im, J.; Choi, H.S.; Kim, S.K.; Woo, S.S.; Ryu, Y.H.; Kang, S.S.; Yun, C.H.; Han, S.H. A food-born heterocyclic amine, 2-amino-1methyl-6-phenylimidazo[4,5-b]pyridine (PhIP), suppresses tumor necrosis factor- $\alpha$ expression in lipoteichoic acid-stimulated RAW 264.7 cells. Cancer Lett. 2009, 274, 109-117. [CrossRef] [PubMed]

125. Gibis, M.; Weiss, J. Antioxidant capacity and inhibitory effect of grape seed and rosemary extract in marinades on the formation of heterocyclic amines in fried beef patties. Food Chem. 2012, 134, 766-774. [CrossRef] [PubMed]

126. Ahn, J.; Grün, I.U. Heterocyclic amines: 2. inhibitory effects of natural extracts on the formation of polar and nonpolar heterocyclic amines in cooked beef. J. Food Sci. 2006, 70, C263-C268. [CrossRef]

127. Schwab, C.E.; Huber, W.W.; Parzefall, W.; Hietsch, G.; Kassie, F.; Schulte-Hermann, R.; Knasmüller, S. Search for compounds that inhibit the genotoxic and carcinogenic effects of heterocyclic aromatic amines. Crit. Rev. Toxicol. 2000, 30, 1-69. [CrossRef]

128. Egbuonu, A.; Osuji, C. Proximate compositions and antibacterial activity of citrus sinensis (sweet orange) peel and seed extracts. Eur. J. Med. Plants 2016, 12, 1-7. [CrossRef]

129. Dhawan, A.; Anderson, D.; De Pascual-Teresa, S.; Santos-Buelga, C.; Clifford, M.N.; Ioannides, C. Evaluation of the antigenotoxic potential of monomeric and dimeric flavanols, and black tea polyphenols against heterocyclic amine-induced DNA damage in human lymphocytes using the Comet assay. Mutat. Res. Genet. Toxicol. Environ. Mutagen. 2002, 515, 39-56. [CrossRef]

130. Anand, T.; Sundararajan, M.; Anbukkarasi, M.; Thomas, P.A.; Geraldine, P. A Methanolic extract of Ocimum basilicum exhibits antioxidant effects and prevents selenite-induced cataract formation in cultured lenses of wistar rats. Pharmacogn. J. 2019, 11, 496-504. [CrossRef]

131. Oguri, A.; Suda, M.; Totsuka, Y.; Sugimura, T.; Wakabayashi, K. Inhibitory effects of antioxidants on formation of heterocyclic amines. Mutat. Res. Fundam. Mol. Mech. Mutagen. 1998, 402, 237-245. [CrossRef]

132. Tsen, S.Y.; Ameri, F.; Smith, J.S. Effects of rosemary extracts on the reduction of heterocyclic amines in beef patties. J. Food Sci. 2006, 71, 469-473. [CrossRef]

133. Melo, A.; Viegas, O.; Petisca, C.; Pinho, O.; Ferreira, I.M.P.L.V. Effect of beer/red wine marinades on the formation of heterocyclic aromatic amines in pan-fried beef. J. Agric. Food Chem. 2008, 56, 10625-10632. [CrossRef] [PubMed] 
134. Busquets, R.; Puignou, L.; Galceran, M.T.; Skog, K. Effect of red wine marinades on the formation of heterocyclic amines in fried chicken breast. J. Agric. Food Chem. 2006, 54, 8376-8384. [CrossRef] [PubMed]

135. Vitaglione, P.; Fogliano, V. Use of antioxidants to minimize the human health risk associated to mutagenic/carcinogenic heterocyclic amines in food. J. Chromatogr. B Anal. Technol. Biomed. Life Sci. 2004, 802, 189-199. [CrossRef] [PubMed]

136. Gibis, M.; Weiss, J. Inhibitory effect of marinades with hibiscus extract on formation of heterocyclic aromatic amines and sensory quality of fried beef patties. Meat Sci. 2010, 85, 735-742. [CrossRef] [PubMed]

137. Shin, H.S.; Park, H.; Park, D. Influence of different oligosaccharides and inulin on heterocyclic aromatic amine formation and overall mutagenicity in fried ground beef patties. J. Agric. Food Chem. 2003, 51, 6726-6730. [CrossRef] [PubMed]

138. Gibis, M.; Schuh, V.; Allard, K.; Weiss, J. Influence of molecular weight and degree of substitution of various carboxymethyl celluloses on unheated and heated emulsion-type sausage models. Carbohydr. Polym. 2017, 159, 76-85. [CrossRef]

139. Tengilimoglu-Metin, M.M.; Hamzalioglu, A.; Gokmen, V.; Kizil, M. Inhibitory effect of hawthorn extract on heterocyclic aromatic amine formation in beef and chicken breast meat. Food Res. Int. 2017, 99, 586-595. [CrossRef]

140. Oz, F. Quantitation of heterocyclic aromatic amines in ready to eat meatballs by ultra fast liquid chromatography. Food Chem. 2011, 126, 2010-2016. [CrossRef] [PubMed]

141. Shin, H.S.; Ustunol, Z. Influence of honey-containing marinades on heterocyclic aromatic amine formation and overall mutagenicity in fried beef steak and chicken breast. J. Food Sci. 2006, 69, FCT147-FCT153. [CrossRef]

142. Rauscher, R.; Edenharder, R.; Platt, K.L. In vitro antimutagenic and in vivo anticlastogenic effects of carotenoids and solvent extracts from fruits and vegetables rich in carotenoids. Mutat. Res. Genet. Toxicol. Environ. Mutagen. 1998, 413, 129-142. [CrossRef]

143. Ito, N.; Hasegawa, R.; Imaida, K.; Tamano, S.; Hagiwara, A.; Hirose, M.; Shirai, T. Carcinogenicity of 2-amino-1-methyl-6phenylimidazo[4,5-b]pyridine (PhIP) in the rat. Mutat. Res. Fundam. Mol. Mech. Mutagen. 1997, 376, 107-114. [CrossRef]

144. Edenharder, R.; Sager, J.W.; Glatt, H.; Muckel, E.; Platt, K.L. Protection by beverages, fruits, vegetables, herbs, and flavonoids against genotoxicity of 2-acetylaminofluorene and 2-amino-1-methyl-6-phenylimidazo[4,5-b]pyridine (PhIP) in metabolically competent V79 cells. Mutat. Res. Genet. Toxicol. Environ. Mutagen. 2002, 521, 57-72. [CrossRef]

145. Bao, X.; Miao, J.; Fan, Y.; Lai, K. The effective inhibition of the formation of heterocyclic aromatic amines via adding black pepper in fried tilapia fillets. J. Food Process. Preserv. 2020, 44. [CrossRef]

146. Ren, X.; Wang, W.; Bao, Y.; Zhu, Y.; Zhang, Y.; Lu, Y.; Peng, Z.; Zhou, G. Isorhamnetin and hispidulin from tamarix ramosissima inhibit 2-amino-1-methyl-6-phenylimidazo[4,5-b]Pyridine (PhIP) formation by trapping phenylacetaldehyde as a key mechanism. Foods 2020, 9, 420. [CrossRef] [PubMed]

147. Mehr, A.E.; Hosseini, S.E.; Seyadain Ardebili, S.M. Effects of nutmeg and ginger essential oils and their nanoemulsions on the formation of heterocyclic aromatic amines and polycyclic aromatic hydrocarbons in beef patties during 90 days freezing storage. J. Food Meas. Charact. 2019, 13, 2041-2050. [CrossRef]

148. Teng, H.; Chen, Y.; Lin, X.; Lv, Q.; Chai, T.T.; Wong, F.C.; Chen, L.; Xiao, J. Inhibitory effect of the extract from Sonchus olearleu on the formation of carcinogenic heterocyclic aromatic amines during the pork cooking. Food Chem. Toxicol. 2019, 129, 138-143. [CrossRef] [PubMed]

149. Cvetkovic, S.; Djukanovic, S.; Mitic-Culafic, D.; Nastasijevic, B.; Knezevic-Vukcevic, J.; Nikolic, B. Protective effect of Gentiana lutea root and leaf extracts against heterocyclic aromatic amines IQ and PhIP produced in thermally processed meat. In Proceedings of the IOP Conference Series: Earth and Environmental Science, Kopaonik, Serbia, 22-25 September 2019; IOP Publishing: Bristol, UK, 2019; Volume 333.

150. Khan, I.A.; Liu, D.; Yao, M.; Memon, A.; Huang, J.; Huang, M. Inhibitory effect of Chrysanthemum morifolium flower extract on the formation of heterocyclic amines in goat meat patties cooked by various cooking methods and temperatures. Meat Sci. 2019, 147, 70-81. [CrossRef]

151. Zeng, M.; Wang, J.; Zhang, M.; Chen, J.; He, Z.; Qin, F.; Xu, Z.; Cao, D.; Chen, J. Inhibitory effects of Sichuan pepper (Zanthoxylum bungeanum) and sanshoamide extract on heterocyclic amine formation in grilled ground beef patties. Food Chem. 2018, 239, 111-118. [CrossRef]

152. Zeng, M.; Zhang, M.; He, Z.; Qin, F.; Tao, G.; Zhang, S.; Gao, Y.; Chen, J. Inhibitory profiles of chilli pepper and capsaicin on heterocyclic amine formation in roast beef patties. Food Chem. 2017, 221, 404-411. [CrossRef] [PubMed]

153. Zhang, Y.; Luo, Z.; Shao, Z.; Yu, C.; Wang, S. Effects of antioxidants of bamboo leaves and flavonoids on 2-amino-1-methyl-6phenylimidazo[4,5-b]pyridine (PhIP) formation in chemical model systems. J. Agric. Food Chem. 2014, 62, 4798-4802. [CrossRef] [PubMed]

154. Puangsombat, K.; Smith, J.S. Inhibition of heterocyclic amine formation in beef patties by ethanolic extracts of rosemary. J. Food Sci. 2010, 75, 47. [CrossRef] [PubMed]

155. Quelhas, I.; Petisca, C.; Viegas, O.; Melo, A.; Pinho, O.; Ferreira, I.M.P.L.V.O. Effect of green tea marinades on the formation of heterocyclic aromatic amines and sensory quality of pan-fried beef. FCT 2010, 122, 98-104. [CrossRef]

156. Cheng, K.W.; Chen, F.; Wang, M. Inhibitory activities of dietary phenolic compounds on heterocyclic amine formation in both chemical model system and beef patties. Mol. Nutr. Food Res. 2007, 51, 969-976. [CrossRef]

157. Persson, E.; Graziani, G.; Ferracane, R.; Fogliano, V.; Skog, K. Influence of antioxidants in virgin olive oil on the formation of heterocyclic amines in fried beefburgers. Food Chem. Toxicol. 2003, 41, 1587-1597. [CrossRef]

158. Vitaglione, P.; Monti, S.M.; Ambrosino, P.; Skog, K.; Fogliano, V. Carotenoids from tomatoes inhibit heterocyclic amine formation. Eur. Food Res. Technol. 2002, 215, 108-113. [CrossRef] 
159. Monti, S.M.; Ritieni, A.; Sacchi, R.; Skog, K.; Borgen, E.; Fogliano, V. Characterization of phenolic compounds in virgin olive oil and their effect on the formation of carcinogenic/mutagenic heterocyclic amines in a model system. J. Agric. Food Chem. 2001, 49, 3969-3975. [CrossRef]

160. Lee, H.J.; Yoon, D.K.; Lee, N.Y.; Lee, C.H. Effect of aged and fermented garlic extracts as natural antioxidants on lipid oxidation in pork patties. Food Sci. Anim. Resour. 2019, 39, 610-622. [CrossRef] [PubMed]

161. Fuzzati, N. Analysis methods of ginsenosides. J. Chromatogr. B 2004, 812, 119-133. [CrossRef]

162. Fraga, C.G.; Oteiza, P.I. Iron toxicity and antioxidant nutrients. Toxicology 2002, 180, 23-32. [CrossRef]

163. Gobert, M.; Rémond, D.; Loonis, M.; Buffière, C.; Santé-Lhoutellier, V.; Dufour, C. Fruits, vegetables and their polyphenols protect dietary lipids from oxidation during gastric digestion. Food Funct. 2014, 5, 2166-2174. [CrossRef]

164. Lund, M.N.; Ray, C.A. Control of Maillard reactions in foods: strategies and chemical mechanisms. J. Agric. Food Chem. 2017, 65, 4537-4552. [CrossRef] [PubMed]

165. Gibis, M. Effect of oil marinades with garlic, onion, and lemon juice on the formation of heterocyclic aromatic amines in fried beef patties. J. Agric. Food Chem. 2007, 55, 10240-10247. [CrossRef] [PubMed]

166. Račkauskienè, I.; Pukalskas, A.; Venskutonis, P.R.; Fiore, A.; Troise, A.D.; Fogliano, V. Effects of beetroot (Beta vulgaris) preparations on the Maillard reaction products in milk and meat-protein model systems. Food Res. Int. 2015, 70, 31-39. [CrossRef]

167. Shin, H.S.; Rodgers, W.J.; Strasburg, G.M.; Gray, J.I. Reduction of heterocyclic aromatic amine formation and overall mutagenicity in fried ground beef patties by organosulfur compounds. J. Food Sci. 2002, 67, 3304-3308. [CrossRef]

168. Schoch, A. Chemical and physical parameter effects on the formation of heterocyclic aromatic amines (HAA) in model systems and hamburger-model products. Fortschr. Ber. VDI Reihe 14 Landtech./Lebensm. 2003, 110.

169. Murkovic, M. Formation of heterocyclic aromatic amines in model systems. J. Chromatogr. B Anal. Technol. Biomed. Life Sci. 2004, 802, 3-10. [CrossRef] [PubMed]

170. Lee, S.Y.; Yim, D.G.; Lee, D.Y.; Kim, O.Y.; Kang, H.J.; Kim, H.S.; Jang, A.; Park, T.S.; Jin, S.K.; Hur, S.J. Overview of the effect of natural products on reduction of potential carcinogenic substances in meat products. Trends Food Sci. Technol. 2020, 99, 568-579. [CrossRef] 